
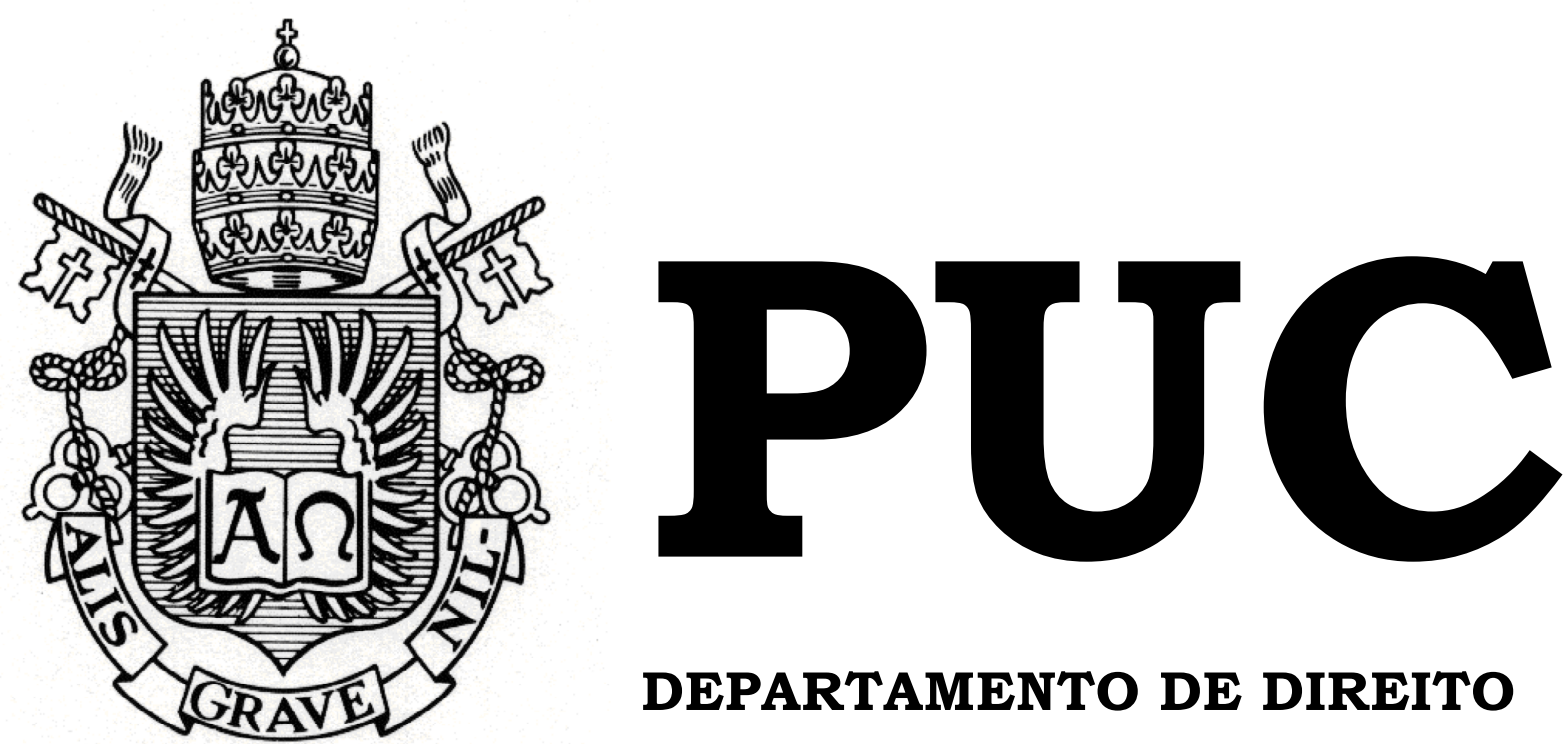

DEPARTAMENTO DE DIREITO

\title{
"DIREITO À HONRA E À IMAGEM COMO LIMITAÇÕES À LIBERDADE DE EXPRESSÃO NA LINGUAGEM HUMORÍSTICA"
}

por

JULIA FONTES ABRAMOF

ORIENTADOR: Fábio Carvalho Leite

2014.2

PONTIFÍCIA UNIVERSIDADE CATÓLICA

DO RIO DE JANEIRO

RUA MARQUÊS DE SÃO VICENTE, 225 - CEP 22453-900

RIO DE JANEIRO - BRASIL 


\title{
Direito à honra e à imagem como limitações à liberdade de expressão na linguagem humoristica
}

\author{
por \\ JULIA FONTES ABRAMOF
}

Monografia apresentada ao Departamento de Direito da Pontificia Universidade Católica do Rio de Janeiro (PUC-Rio) para a obtenção do Título de Bacharel em Direito.

Orientador:

Fábio

Carvalho Leite 
Dedico o presente trabalho a minha mãe, por sempre me apoiar, $e$ me incentivar a realizar os meus sonhos. 


\section{AGRADECIMENTOS}

Primeiramente, agradeço a Deus por me abençoar, me guiar e me proteger.

Agradeço aos meus pais, Ricardo e Dione, sem os quais eu não seria quem eu sou, e por todo apoio, confiança, amor e carinho dedicados a mim durante toda a minha vida.

Aos meus irmãos, Cecília e Bernardo, pela paciência e ajuda enquanto eu estava escrevendo este trabalho, e, pelo companheirismo sempre.

Ao meu amor, Caio, pelo apoio, conversas, e momentos juntos.

Ao Professor Fábio Leite, por toda a atenção, carinho e ensinamentos.

Muito obrigada! 


\section{RESUMO}

O humor toma cada vez mais espaço nos meios de comunicação, levando ao seu telespectador, através do jornalismo humorístico um novo olhar sobre as situações cotidianas. Por muito, a liberdade de expressão não podia ser livremente exercida, devido às restrições sofridas durante o regime militar brasileiro, e hoje o é. Contudo, humoristas, jornalistas e artistas em geral conseguiram criar a chamada publicação alternativa, que utilizava o humor, a música, a literatura, e o teatro, como forma de criticar o regime e denunciar as injustiças sociais cometidas na época. O humor, criado a partir do uso de diferentes técnicas linguísticas, como piada, ironia, imitação e sátira, se tornou um dos recursos mais utilizados àqueles que buscam manifestar seus pensamentos e opiniões livremente, tendo em vista que lhes permite criticar ou informar situações ou pessoas usando uma linguagem mais leve e coloquial. Sendo, portanto, manifestação da liberdade de expressão, goza da proteção constitucional aos direitos fundamentais. Todavia, é sabido que tais direitos não usufruem de uma proteção absoluta, podendo ter seu alcance restringido por outro direito fundamental, de igual valor e hierarquia. As limitações à liberdade de expressão, ao menos na manifestação do seu caráter humorístico, decorrem, principalmente, dos direitos à honra e à imagem. O conflito entre direitos fundamentais é recorrente nos tribunais brasileiros e, é resolvido através da técnica da ponderação. Com base no estudo de ações judiciais que têm como objeto o conflito entre o direito à liberdade de expressão e os direito à honra e à imagem, este trabalho visa analisar como o humor nos meios de comunicação é afetado pela proteção do direito à honra, à imagem e as técnicas utilizadas pelos tribunais na resolução dos conflitos.

\section{Palavras-Chave:}

Liberdade de expressão; Humor; Direito à honra, Direito à imagem; Conflito entre direitos fundamentais; Ponderação. 


\section{SUMARIO}

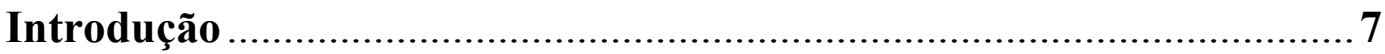

Capítulo 1 - Breve Análise da Liberdade de expressão no Brasil ........11

1.1. A Liberdade na Ditadura Militar (1964 - 1985)............................ 11

1.2. Liberdade de Expressão na CRFB/88: análise dos dispositivos e interpretação doutrinária .................................................................. 15

1.3. Direito à Honra e direito à Imagem como limitadores da liberdade de expressão

\section{Capítulo 2 - O Humor como Manifestação da Liberdade de expressão}

2.1. As diferentes manifestações da linguagem humorística: piada, ironia,

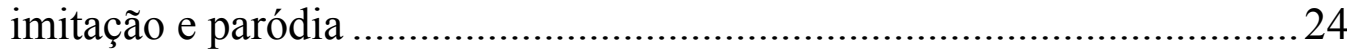

$2.2 \mathrm{O}$ humor como veículo de informação...........................................22

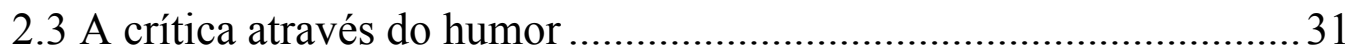

Capítulo 3 - Os Princípios Limitadores e o Conflito no Judiciário ....... 37

3.1. Considerações gerais acerca dos limites à liberdade de expressão ..37

3.2. Principais direitos limitadores ao humor na Constituição Brasileira 41

3.2.1. Direito à Honra ...................................................................... 41

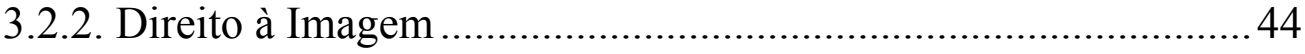

3.3. Análise de casos julgados pelos tribunais Brasileiros .................... 46

3.3.1. Breve Estudo de Casos ......................................................... 46

3.3.2. A Ponderação como forma de resolução dos conflitos ..............53

3.3.3. Critérios de avaliação adotados pelos tribunais ........................55

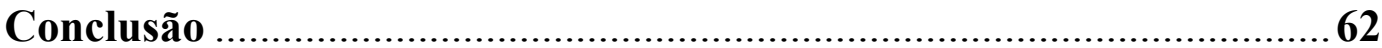

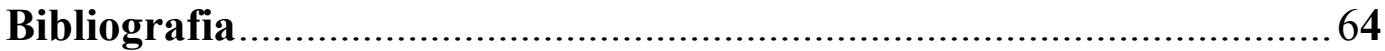




\section{ABREVIATURAS}

ADI - Ação Direta de Inconstitucionalidade

STF - Supremo Tribunal Federal

STJ - Superior Tribunal de Justiça

MIN. - Ministro

REL.- Relator

DES. - Desembargador

ART. - Artigo

No. - Número

TRE - Tribunal Regional Eleitoral 


\section{INTRODUÇÃO}

O presente trabalho tem como objeto a análise acerca do uso do humor como manifestação da liberdade de expressão e sua limitação pelo direito à honra e o direito à imagem.

A liberdade de expressão, direito fundamental positivado no direito brasileiro no art. $5^{\circ}$ da Constituição Federal (CF), é um dos direitos de maior relevância no estado democrático, haja vista que é através de seu exercício que decorrem diversos outros como a liberdade de opinião, a liberdade de comunicação ou informação e, a liberdade intelectual, que, por sua vez, compreende as formas de criação, expressão e manifestação do pensamento e de informação, bem como a organização dos meios de comunicação. Alguns autores defendem que a proteção constitucional garantida aos autores de obras literárias, artísticas e científicas também seria um direito conexo.

Não obstante, cumpre lembrar que, no Brasil, essa proteção não foi sempre garantida. Durante a ditadura militar (abril de 1964 até março de 1985) e, principalmente após a edição do Ato Institucional No. 5, a censura era fortemente aplicada e críticas ao governo não eram bem aceitas. Nesse contexto, a Lei de Imprensa exerceu papel fundamental, pois regulava os meios de comunicação e impedia que os acontecimentos relacionados à atividade governamental fossem narrados com precisão e veracidade.

Diante deste cenário, não é de surpreender que a censura seja expressamente proibida pela nossa Constituição Federal, deixando claro que nenhuma lei conterá dispositivo que possa constituir embaraço à plena liberdade de informação jornalística em qualquer veículo de comunicação social.

O foco do trabalho será no humor e como ele é usado nos meios de comunicação. O cômico é obtido através do uso de alguns recursos de linguagem: piada, ironia, imitação, e paródia. $\mathrm{O}$ humor não serve apenas para garantir diversão e provocar o riso; pode também ser importante 
veículo de informação. O humor permite que as notícias do cotidiano sejam transmitidas ao telespectador com maior leveza e uma linguagem mais acessível e se tornou popular em programas de TV como o CQC, transmitido pela Band. O jornalismo humorístico não é, contudo, exclusivo aos programas humorísticos, sendo muito utilizado no jornalismo impresso. Nesse ultimo caso, o humor é comumente usado para criticar situações ou pessoas. Essa crítica é manifestada através do uso de charges e caricatura, por exemplo.

O humor faz parte da rotina de grande parte da população, e o jornalismo humorístico ganha importante papel na sociedade. Através de seu uso, podemos garantir ao público conhecimento acerca de assuntos do cotidiano, sejam eles relacionados ao governo, à população ou ao mundo.

Cumpre indagar, no entanto, se existem alguns assuntos que não poderiam ser retratados no âmbito do jornalismo humorístico devido à sua seriedade. Em que pese ao brasileiro ser bem-humorado e fazer piada de tudo, existem alguns assuntos que viram verdadeiros tabus. Seria o caso, por exemplo, das torturas cometidas durante a ditadura militar que, por terem acontecido em um período relativamente recente e serem tão pouco comentadas, se tornam quase que um "assunto proibido".

A jurisprudência brasileira entende que sim, contando com alguns acórdãos em que o assunto da piada foi objeto de condenação. $\mathrm{Na}$ ação 11.201838-5 $5^{1}$, proposta por Wanessa Camargo, seu marido, e seu filho nascituro, contra Rafinha Bastos, este foi condenado ao pagamento de uma indenização a titulo de danos morais por ter dito que "comeria ela e o bebê" quando ainda era apresentador do programa CQC. O juiz que proferiu a sentença entendeu que o nascituro era titular do direito à honra e à imagem e, portanto, teria direito à indenizaçao devido à ofensa sofrida. Afirmou ainda que:

\footnotetext{
${ }^{1}$ Processo número 583.00.2011.201838-5. $18^{\mathrm{a}}$ vara Cível de Sao Paulo . Sentença proferida pelo juiz Luiz Beethoven Giffoni Ferreira. Disponível em: http://www.dizerodireito.com.br/2012/01/como-muitos-de-voces-ja-devem-saber-o.html. Acesso em 01 de nov. de 2014.
} 
Uma imprensa livre, mas com responsabilidade, é indispensável fator de progresso em qualquer Nação livre; há de se considerar, entretanto, que a informação, por estar inserida no campo do espírito, da livre manifestação do pensamento, que é um dos direitos mais preciosos do homem, conforme se vê no Art.11 da Declaração Universal dos Direitos do Homem, na Revolução Francesa, há mesmo que ser prestada de forma precisa e respeitando toda a restante gama de direitos e garantias fundamentais do cidadão, tais como o da intimidade, a liberdade de culto e crença, mas sobretudo a garantia acerca da honra e da imagem das pessoas.

Podemos incluir aqui também as piadas que retratam o preconceito e racismo na sociedade, como uma de autoria de Danilo Gentili que diz o seguinte: "King Kong, um macaco que, depois que vai para a cidade e fica famoso, pega uma loira. Quem ele acha que é? Jogador de futebol?’. A piada, por mais que alguns a achem engraçada, carrega, sem dúvida, uma conotação racista para com negros e jogadores de futebol. Infelizmente, esse tipo de piada ainda é assustadoramente comum na sociedade, não apenas contra negros, mas também contra loiras, homossexuais, e mulheres, que ainda são retratadas por muitos como se viessem ao mundo com o exclusivo propósito de "servir seu marido".

O humor, importante instrumento que é, deve ser utilizado de forma mais inteligente e responsável, servindo a um propósito maior: denunciar injustiças sociais, possibilitando que o telespectador crie um senso crítico sobre as situações retratadas. O humor pode, e deve, ser um instrumento de amadurecimento da sociedade para com assuntos pouco discutidos, e não um que confirme estereótipos e perpetue o preconceito.

No mais, a liberdade de expressão, compreendida como o direito à livre manifestação do pensamento e o direito do cidadão a ser informado, deve poder ser exercida livremente. O que percebemos é que, na teoria, todos prezam e enaltecem o direito à liberdade de expressão, mas na prática, quando é verificado um conflito com outros direitos fundamentais, esse é o primeiro a ser limitado. Nas palavras do Professor Fábio Leite: 
É curioso constatar que, em geral, há uma defesa apaixonada a favor da liberdade de expressão, compreendida esta apenas como uma garantia contra a censura prévia, mas que é abandonada logo na primeira esquina quando o conteúdo em questão é divulgado. ${ }^{2}$

Evidentemente, o direito à liberdade de expressão não é absoluto e nem deve ser tratado como tal, tendo em vista que, assim como os demais direitos fundamentais, comporta restrições. Vemos que os direitos que mais conflitam com o direito à liberdade de expressão são os direitos à honra e à imagem. Esses direitos e a forma como eles limitam o uso do humor será analisado mais profundamente no decorrer do trabalho.

\footnotetext{
${ }^{2}$ LEITE, Fábio Carvalho. Liberdade de Expressão e Direito à Honra: novas diretrizes para um velho problema. In CLEVE, Clemerson Merlin, FREIRE, Alexandre (Org.) Direitos Fundamentais e Jurisdição Constitucional. São Paulo: Ed. Revista dos Tribunais, 2014 (no prelo).
} 


\section{CAPITULO I - BREVE ANALISE DA LIBERDADE DE EXPRESSÃO NO BRASIL}

\subsection{Liberdade de Expressão na Ditadura Militar (1964 - 1985)}

No atual cenário democrático brasileiro, a liberdade de expressão é enquadrada no rol de Direitos Fundamentais, e respeitada como tal. No entanto, durante a ditadura militar, que perdurou desde o dia 1 de abril de 1964 até 15 de março de 1985, predominava a censura e a repressão. Aqueles que se posicionavam contra o regime foram perseguidos e torturados. Durante os 21 anos da ditadura, foram observados períodos de maior abertura política, e momentos de endurecimento do regime, o qual analisaremos a seguir.

O Ato Institucional No 5 foi o ápice da repressão, que marcou o início dos chamados "anos de chumbo" do governo militar. Esse ato permitia ao Presidente decretar o recesso do Congresso Nacional, das Assembléias Legislativas e das Câmaras de Vereadores, que só voltariam a funcionar quando o próprio Presidente convocasse essas organizações, bem como decretar a intervenção nos estados e municípios, sem as limitações previstas na Constituição. Com esse ato, todas os direitos e prerrogativas democráticas estavam oficialmente suspensos, e teve como conseqüência a usurpação de uma série de garantias constitucionais.

Assim, a censura desempenhou papel fundamental na implementação e consolidação da ditadura, servindo de instrumento que ora silenciava uns e ora servia a outros. Para o exercício da censura praticada pelo Governo, foram criados órgãos de controle, como o Serviço Nacional de Informação (SNI), cuja principal função era realizar escutas telefônicas, gravações e fichamentos, mas também se fazia presente no campo político, revistas e rádios. O SNI, junto com o Conselho de Segurança Nacional (CSN), era encarregado de reprimir organizações de esquerda, despolitizar universidades e perseguir seus dissidentes como também coibir a produção 
artística e cultural que contrariassem a doutrina imposta pelo regime ${ }^{3}$.

Nesse contexto, foi instituída a Lei 5250, em 9 de fevereiro de 1967, conhecida como a Lei de Imprensa através da qual a imprensa brasileira foi impedida de exercer função inerente à sua profissão: informar os fatos com precisão e veracidade. A imprensa e os órgãos de comunicação tinham pouca liberdade para narrar verdadeiramente o que estava acontecendo no país. A censura imposta sobre os veículos de informação foi uma maneira encontrada pelo Estado de se proteger, ocultando da população os abusos que o regime autoritário cometia. Além disso, a lei também previa uma série de punições severas aos jornalistas que cometessem abusos, atos que atentavam contra a moral e os bons costumes, e crimes classificados como injúria $^{4}$, calúnia ${ }^{5}$ ou difamação ${ }^{6}$. Aqueles que não se submetessem à censura eram vítimas de perseguições e torturas.

Diante desse cenário, o Brasil experimentou uma rica e expressiva manifestação artística e cultural na história do País. Como meios alternativos para se expressar sem cair nas garras dos órgãos de controle, surgiram as chamadas publicações alternativas, que utilizavam a música, a literatura, o teatro e o humor, como forma de criticar o regime, e ao mesmo tempo, driblar as regras impostas pelo governo. Esse movimento ficou conhecido como a cultura do protesto, e muitos destes, como a de publicação de receita de bolo nos periódicos, ou canções com mensagens subliminares, passaram despercebidos pelos órgãos de fiscalização do governo, e ganharam notoriedade.

A cultura do protesto, que encontrava respaldo nas publicações alternativas, foi surgindo na medida em que a crítica foi ficando cada vez menos tolerada, fazendo com que artistas, intelectuais e jornalistas

\footnotetext{
${ }^{3}$ COSTA, Cristina. Censura em cena: teatro e censura no Brasil. São Paulo: EDUSP: FAPESP: Imprensa oficial do Estado de São Paulo, 2006. p 181-182

${ }^{4}$ BRASIL, Código Penal. Definição de Injúria, In. Código penal: ”Art. 140 - Injuriar alguém, ofendendo-lhe a dignidade ou o decoro: (...)".

${ }^{5}$ BRASIL, Código Penal. Definição de Calúnia. In. Código Penal: Art. 138 - Caluniar alguém, imputando-lhe falsamente fato definido como crime: (...)"

${ }^{6}$ BRASIL, Código Penal. Definição de Difamação. In Código Penal: Art. 139 - Difamar alguém, imputando-lhe fato ofensivo à sua reputação: (...)"
} 
contribuíssem para, juntos, criarem projetos alternativos. Algumas dessas publicações alternativas, entre muitas outras, foram amplamente divulgadas, como Pasquim, Opinião, Movimento, Lampião da Esquina, Em Tempo, Brasil Mulher, Beijo, Ex, Versu' ${ }^{7}$, que circularam entre os anos de 1964 a 1984 no Brasil, e ousaram, quebrando o silêncio que predominava sobre a imprensa. Esses eram jornais de pequeno porte comandados por jornalistas, intelectuais, estudantes universitários e políticos que sofreram, direta ou indiretamente, censura ou repressão pelo regime, e buscavam maneiras alternativas de expressar seu descontentamento e suas críticas com o mesmo.

O humor era amplamente usado nessas publicações alternativas, tendo sido criados diversos personagens no âmbito dos jornais supramencionados, que tinham o perfil de seus editores, e ilustravam os temores sofridos pela população naquela época. Um dos jornais que mais ganharam notoriedade pela utilização do humor e de seus personagens foi o Pasquim, que circulou semanalmente na cidade do Rio de Janeiro durante os anos de 1969 a 1991.

O Pasquim fez uso de charges como um meio de contestação e crítica do regime militar, atuando como um meio de expressão político da sociedade. Henrique de Souza Filho, um intelectual de esquerda e militante do Partido dos Trabalhadores (PT), era o principal cartunista do jornal, e assim criou diversos personagens famosos como Fradins, a Graúna, o nordestino Zeferino, Bode Orelana e Ubaldo o paranóico. Cada personagem possuía características próprias que refletiam o momento e a situação vivida pela própria população brasileira, possibilitando uma identificação instantânea com o seu leitor.

Ubaldo, o paranóico, um de seus personagens mais emblemáticos, foi criado no ano de 1975, logo após a morte do jornalista Vladimir Herzog, refletindo o medo de perseguição e a constante vigilância vivida naquela

\footnotetext{
${ }^{7}$ ROSA, Susel de Oliviera da. "Apesar de voces amanha vai ser um outro dia" Imprensa alternativa versus ditadura militar. Porto Alegre: PPG - LET - UFRGS, 2005. Disponível em http://www.seer.ufrgs.br/NauLiteraria/article/viewFile/4850/2768. Acessado em 24/10/2014.
} 
época, que gerava uma autocensura por parte da população, que tinha medo de agir espontaneamente, devido à reação que suas atitudes ou palavras podiam provocar.

\begin{abstract}
A ideia de fazer o Ubaldo foi justamente de colocar a nu a perseguição. Por quê? Porque pouco se fala dela. Porque muita gente acha que ela não existe, porque ela se tornou tão forte que numa reação de defesa gigantesca as pessoas evitam pensar nela para não se anularem de medo. Não pensando, não existe, né? Porque muita gente engoliu tanto medo que ficou incapaz de perceber a perseguição nelas (a paranóia neste caso como doença mesmo). (...) Ubaldo é filho da perseguição. Só que a historinha mostra, além da perseguição real, a criação que Ubaldo faz por conta própria.(...) E acho também que Ubaldo é jornalismo. Estou informando que em 1976 as pessoas estavam com medo de falar no telefone, por exemplo. ${ }^{8}$
\end{abstract}

Os artistas brasileiros na época não se intimidaram pela ditadura militar e, através da arte, buscaram uma maneira de lutar contra ela, mesmo sofrendo forte repressão. No Teatro, algumas peças fizeram história, como a estréia do chamado "teatro de resistência" com o Show Opinião, que se apresentava no Rio de Janeiro, e Arena conta Zumbi, cujos autores Augusto Boal e Gianfrancesco Guarnieri apresentavam diferentes formas de opressão que marcavam a época através de metáforas. Roda Viva, de Chico Buarque de Hollanda, se tornou exemplo de "guerrilha teatral" ${ }^{9}$. Na música, os protestos se transformavam em verdadeiros "gritos de guerra" e "hinos de protestos"10 ${ }^{10}$, tornou notórias músicas como Prá não dizer que não falei das flores, de Geraldo Vandré. No entanto, nada disso ocorria pacificamente ou passava despercebido pelas autoridades; aqueles que criticavam o atual regime e suas políticas eram duramente perseguidos.

Ao longo dos anos a opressão e perseguição aos artistas foi ficando cada vez pior, fazendo com que muitos se exilassem na Europa, prática que se tornou comum na década de 70. Foi somente no início dos anos 80 que se pôde notar uma gradual abertura política e libertação da manifestação do pensamento, que com a promulgação da Constituição de 1988, conhecida

\footnotetext{
${ }^{8}$ Revista do Fradim, n. 16, pp 44/46.

${ }^{9}$ COSTA, Cristina. Op. Cit. p 190

${ }^{10}$ Ibid.
} 
como a "Constituição Cidadã", foi consagrada no ordenamento jurídico brasileiro.

\subsection{Liberdade de Expressão na Constituição Brasileira de 1988: análise dos dispositivos e interpretação doutrinária}

A liberdade de expressão, direito de difícil conceituação por sua amplitude, é um dos pilares da democracia, tendo lhe sido garantida uma posição de destaque no texto da Constituição da República de 1988.

\footnotetext{
Art. $5^{\circ}$ Todos são iguais perante a lei, sem distinção de qualquer natureza, garantindo-se aos brasileiros e aos estrangeiros residentes no País a inviolabilidade do direito à vida, à liberdade, à igualdade, à segurança e à propriedade, nos termos seguintes:

(...)

IX - é livre a expressão da atividade intelectual, artística, científica e de comunicação, independentemente de censura ou licença;
}

De fato, é um direito fundamental que deve ser interpretado e aplicado em conjunto com os demais direitos fundamentais, em observância ao Princípio da Indivisibilidade dos Direitos Fundamentais, onde estes se complementam e são interdependentes.

Da liberdade de expressão decorre uma série de direitos que encontram neste seu pressuposto, tornando-os conexos. Essa pode ser exercida através da liberdade de opinião, adotando uma linha de raciocínio, pensamento, ou atitude intelectual a qual entenda ser a mais razoável, como também através da liberdade de comunicação ou informação, o que, segundo José Afonso da Silva, poder ser extraída dos incisos IV, V, IX, XII e XIV do art. 50 c/c Capítulo V da CRFB/88:

IV - é livre a manifestação do pensamento, sendo vedado o anonimato; V - é assegurado o direito de resposta, proporcional ao agravo, além da indenização por dano material, moral ou à imagem; [...] IX - é livre a expressão da atividade intelectual, artística, científica e de comunicação, independentemente de censura ou licença; ; XII - é inviolável o sigilo da correspondência e das comunicações telegráficas, de dados e das comunicações telefônicas, salvo, no último caso, por ordem judicial, nas hipóteses e na forma que a lei estabelecer para fins de 
investigação criminal ou instrução processual penal;XIV - é assegurado a todos o acesso à informação e resguardado o sigilo da fonte, quando necessário ao exercício profissional $[\ldots]^{11}$

A liberdade intelectual compreende as formas de criação, expressão e manifestação do pensamento e de informação, bem como a organização dos meios de comunicação. $O$ autor enumera alguns princípios que norteariam essa forma de organização dos meios de comunicação:

(i) observado o disposto na Constituição, não sofreram qualquer restrição qualquer que seja o processo ou veículo por que se exprima; (ii) nenhuma lei conterá dispositivo que possa constituir embaraço à plena liberdade de informação jornalística; (iii) é vedada toda e qualquer forma de censura de natureza política, ideológica e artística; (iv) a publicação de veículo impresso de comunicação independe de licença de autoridade; (v) os serviços de radiofusão sonora e de sons e imagens dependem de autorização, concessão ou permissão do Poder Executivo federal, sob controle sucessivo do Congresso Nacional, a que cabe apreciar o ato, no prazo do art. 64, parágrafos 20 e 4o; (vi) os meios de comunicação social não podem, direta ou indiretamente, ser objeto de monopólio. ${ }^{12}$

José Afonso da Silva entende que também a proteção constitucional garantida aos autores de obras literárias, artísticas e científicas seria um direito conexo ${ }^{13}$. O direito autoral garante aos autores o direito exclusivo de utilização, publicação ou reprodução de suas obras (art. 5o, XV da CRFB/88), "a proteção às participações individuais em obras coletivas e à reprodução da imagem e voz humanas, inclusive nas atividades desportivas", e o "direito de fiscalização do aproveitamento econômico das obras que criarem ou de que participarem aos criadores, aos intérpretes e às respectivas representações sindicais e associativas" ${ }^{14}$.

Como forma lato sensu de liberdade de expressão, o autor destaca, no âmbito do inciso IX do art. 5o acima transcrito, a liberdade de expressão intelectual, artística, e científica:

\footnotetext{
${ }^{11}$ SILVA, José Afonso da. Curso de Direito Constitucional Positivo. Malheiros Editores, 34a edição, 2011, p. 243-244

${ }^{12}$ Ibid.

${ }^{13}$ Ibid. p. 241

${ }^{14}$ BRASIL, Constituição da República, art. 5o, inciso XXVIII, alíneas a e b.
} 
[...] as manifestações intelectuais, artísticas e científicas são formas de difusão e manifestação do pensamento, tomado esse termo em sentido abrangente dos sentimentos e dos conhecimentos intelectuais, conceptuais e intuitivos. ${ }^{15}$

A liberdade de expressão é, portanto, um direito com um campo de divulgação amplo, e pode ser percebida como um gênero do qual decorrem várias espécies, e a doutrina e jurisprudência brasileira comumente distinguem a liberdade de expressão e a liberdade de informação. Conforme entendimento de Luís Gustavo Grandinetti, a primeira compreende qualquer meio de livre expressão do pensamento, seja pelo meio artístico, literário, entre outros; já a segunda poderia ser conceituada como uma liberdade civil, individual que teria expressão coletiva." ${ }^{16}$. Já na visão Luis Roberto Barroso, a liberdade de informação está inserida no aspecto geral da liberdade de expressão, diferenciando-as por conta do interesse público inerente à informação. ${ }^{17}$

Daí podemos extrair que a expressão da atividade intelectual encontra amparo legal para ser totalmente livre e desembaraçada. Todos podem, portanto, produzir obras de conteúdo artístico e livremente divulgálas. Na opinião de José Afonso da Silva, algumas expressões artísticas gozam de ampla liberdade, a exemplo das artes plásticas, música e literatura. Outras manifestações, contudo, ficam sujeitas a uma regulamentação especial, como é o caso do art. 220, parágrafo 3o, que destina à lei federal a regulamentação das diversões e espetáculos públicos, bem como os meios legais que permitem o gozo de programas de rádio e televisão que não sejam nocivos à saúde ou ao meio ambiente.

\footnotetext{
${ }^{15}$ SILVA, José Afonso da. Op. Cit. p. 253

${ }^{16}$ CARVAlHO, Luis Gustavo Grandinetti Castanho de. Liberdade de informação e o direito difuso à informação verdadeira. Rio de Janeiro: Editora Renovar. 1999. p. 13

${ }^{17}$ BARROSO, Luis Roberto. Colisão entre liberdade de expressão e direitos da personalidade. Critérios de ponderação. Interpretação constitucionalmente adequada do Código Civil e da Lei de Imprensa. Revista Trimestral de Direito Civil, Rio de Janeiro, v. 16, p. 59-102, 2004.
} 
A Constituição Federal proíbe expressamente qualquer tipo de censura, garantindo a livre manifestação e expressão do pensamento:

Art. 220. A manifestação do pensamento, a criação, a expressão e a informação, sob qualquer forma, processo ou veículo não sofrerão qualquer restrição, observado o disposto nesta Constituição.

$\S 1^{\circ}$ - Nenhuma lei conterá dispositivo que possa constituir embaraço à plena liberdade de informação jornalística em qualquer veículo de comunicação social, observado o disposto no art. $5^{\circ}, \mathrm{IV}, \mathrm{V}, \mathrm{X}, \mathrm{XIII}$ e XIV.

$\S 2^{\circ}-$ É vedada toda e qualquer censura de natureza política, ideológica e artística.

Se por um lado a liberdade de expressão propriamente dita tem garantia constitucional de ser exercida de forma livre e desembaraçada, percebemos no atual contexto jurídico que o mesmo não é aplicado quando diz respeito à liberdade de informação, na medida em que este é posto em conflito com outros direitos fundamentais, em especial, os direitos da personalidade. É preservado em parte da doutrina brasileira o entendimento de que a liberdade de informação só é efetivamente livre quando versar sobre fatos objetivamente verdadeiros e quando for necessária à formação de opinião pública ${ }^{18}$.

A doutrina e jurisprudência brasileira ainda não lograram êxito em definir os limites intrínsecos da liberdade de expressão para evitar possíveis excessos cometidos e, conseqüentemente, violação a outros princípios. Não sabemos, portanto, ao publicar uma matéria de jornal, livro ou similar, o que seria entendido por um tribunal brasileiro como "fora" do alcance da proteção da liberdade de expressão e, logo, punível, caso fosse ajuizada uma ação. A falta de uniformização do entendimento acerca do alcance da liberdade de expressão é capaz de gerar uma responsabilização para o autor que, se desproporcional e injustificada, poderá provocar efeitos idênticos

${ }^{18}$ CARVALHO, Luis Gustavo Grandinetti. Op. Cit. p. 13 
àqueles que seriam produzidos com a censura prévia. Através de uma autocensura por parte do autor, este poderá deixar de publicar um artigo ou obra literária por receio das conseqüências que pode vir a sofrer. Não pode haver, no entanto, impunidade perante um eventual crime ou excesso cometido.

De fato a liberdade de expressão é ponto fundamental de uma democracia, devendo ter suas eventuais restrições aplicadas com muita cautela, sob pena de configurar abuso. Sobre isso, o Ministro Ayres Brito adotou uma posição radical, quando do julgamento ${ }^{19}$ sobre a inconstitucionalidade da Lei de Imprensa, entendendo que a liberdade de expressão não deve sofrer qualquer restrição:

[...] é definitiva lição da História que, em matéria de imprensa, não há espaço para o meio-termo ou a contemporização. Ou ela é inteiramente livre, ou dela já não se pode cogitar senão como jogo de aparência jurídica. [...] consagrar a plenitude de uma liberdade tão intrinsecamente luminosa que sempre compensa, de muito, de sobejo, inumeravelmente, as quedas de voltagem que lhe infligem profissionais [...] numa democracia, o modo mais eficaz de se combater os excessos de liberdade é com mais liberdade ainda.

O Ministro concluiu seu voto com a seguinte afirmação:

Não há como garantir a livre manifestação do pensamento, tanto quanto o direito de expressão lato sensu (abrangendo, então, por efeito do caput do art. 220 da CF, a criação e a informação), senão em plenitude. Senão colocando em estado de momentânea paralisia a inviolabilidade de certas categorias de direitos subjetivos fundamentais, como, por exemplo, a intimidade, a vida privada, a imagem e a honra de terceiros.

Apesar da conclusão do Ministro Ayres Britto sobre a preponderância da liberdade de expressão quando em conflito, essa não é absoluta, assim como qualquer direito fundamental e, portanto, está sujeita a restrições.

\footnotetext{
${ }^{19}$ Argüição de Descumprimento de Preceito Fundamental 130 , julgada pelo Supremo Tribunal Federal, no dia 30/04/2009.
} 


\subsection{Direito à honra e direito à imagem como limitadores da liberdade de expressão: breves considerações.}

Conforme mencionado acima, os direitos fundamentais sofrem restrições decorrentes de sua própria natureza, por serem amplos e gerais. Essas restrições são admissíveis somente quando sua causa também emana de um preceito constitucional. Os direitos fundamentais, por conta de seu conteúdo aberto e sujeito a interpretações, expõem-se a limites, que muitas vezes ocorre devido a conflitos que surgem entre direitos de igual porte. A liberdade de expressão, por sua vez, encontra nos direitos da personalidade, mais especificamente no direito à honra e no direito à imagem, seus principais limitadores.

$\mathrm{O}$ direito à honra e à imagem, bem como à privacidade e à intimidade encontra respaldo na Constituição Federal, no art. 5o, inciso X:

\footnotetext{
Art. $5^{\circ}$ Todos são iguais perante a lei, sem distinção de qualquer natureza, garantindo-se aos brasileiros e aos estrangeiros residentes no País a inviolabilidade do direito à vida, à liberdade, à igualdade, à segurança e à propriedade, nos termos seguintes:

$(\ldots)$

X - são invioláveis a intimidade, a vida privada, a honra e a imagem das pessoas, assegurado o direito a indenização pelo dano material ou moral decorrente de sua violação;
}

Sobre o direito à honra, José Afonso da Silva diz: "A honra é o conjunto de qualidades que caracterizam a dignidade da pessoa, o respeito dos concidadãos, o bom nome, a reputação. É direito fundamental de a pessoa resguardar essas qualidades." ${ }^{20}$. Ao desrespeitar a honra de alguém, através da liberdade de expressão, haverá, na visão do autor, um desrespeito à própria dignidade da mesma, e poderá, portanto, sofrer limitações. Em relação ao direito à imagem, o autor entende que "a inviolabilidade da imagem da pessoa consiste na tutela do aspecto físico, como é perceptível visivelmente.". Entende o autor, portanto, que uma pessoa que tivesse seu

\footnotetext{
${ }^{20}$ SILVA, José Afonso da. Op.. Cit., p. 209
} 
direto à honra ou à imagem violados poderia buscar reparação judicial pelos abusos cometidos.

De fato, o direito à liberdade de expressão está sujeito a sofrer limitações, qualidade inerente a qualquer direito fundamental, e há quem sustente que essa limitação somente deverá ocorrer quando não houver respeito ao dever de veracidade, uma vez que a divulgação de informações falaciosas constitui crime, e se as informações não forem relevantes ao conhecimento da sociedade. Caso contrario, deve prevalecer o direito à liberdade de expressão. Nesse sentido, entendeu o Superior Tribunal de Justiça, no julgamento do REsp 984.803, afirmando que:

[...] a honra e a imagem dos cidadãos não são violados quando se divulgam informações verdadeiras e fidedignas a seu respeito e que, além disso, são do interesse público.

Na visão de Gilmar Mendes, o constituinte autorizou a criação de restrições à liberdade de expressão, por meio da "reserva legal qualificada", visando preservar direitos fundamentais igualmente relevantes ${ }^{21}$, de modo que estaria a liberdade de expressão sujeita a sofrer restrições quando em conflito com outros direitos fundamentais.

Percebe-se que nem sempre é garantida a ampla liberdade de expressão, com entendimentos de esta só é legítima quando exercida respeitando os fatores que a limitam. Assim firmou entendimento o autor Sérgio Cavalieri Filho:

(...) sempre que direitos constitucionais são colocados em confronto, um condiciona o outro atuando como limites estabelecidos pela própria Lei Maior para impedir excessos e arbítrios. Assim, se ao direito à livre expressão da atividade intelectual e de comunicação contrapõe-se o direito à inviolabilidade da intimidade da vida privada, da honra e da imagem, segue-se como conseqüência lógica que este último condiciona o exercício do primeiro. ${ }^{22}$

\footnotetext{
${ }^{21}$ MENDES, Gilmar Ferreira. Colisão de direitos fundamentais: liberdade de expressão $e$ de comunicação $e$ direito à honra $e$ à imagem. Disponível em http://www.gilmarmendes.org.br. Acesso em: 10 de out. de 2014.

${ }^{22}$ CAVAliERI FILHO, Sérgio. Programa de Responsabilidade Civil. 10 Ed. São Paulo: Atlas, 2012, p. 124
} 
É constitucionalmente equivocado afirmar que os direitos da personalidade "condicionam" a liberdade de expressão uma vez que todos possuem a mesma importância frente ao ordenamento jurídico. Não é possível, juridicamente, atribuir maior importância a um direito fundamental em detrimento a outro, dado que teoricamente não há hierarquia entre os direitos fundamentais e todos possuem o mesmo patamar constitucional. No campo prático, vez ou outra, será necessário dar preferência a um direito fundamental em detrimento do outro, mas a restrição do direito que será limitado deverá ser analisada através de critérios objetivos, como o respeito à veracidade e o interesse público, para garantir uniformidade nas decisões e segurança jurídica.

A jurisprudência brasileira elegeu na ponderação a forma utilizada para resolução de conflitos envolvendo princípios com o mesmo grau hierárquico, uma vez que a subsunção ${ }^{23}$ se mostrou ineficaz nesses casos, conforme define o Min. Luis Roberto Barroso ao afirmar que:

(...) a ponderação consiste, portanto, em uma técnica de decisão jurídica aplicável a casos difíceis, em relação aos quais a subsunção se mostrou insuficiente, sobretudo quando uma situação concreta dá ensejo à aplicação de normas de mesma hierarquia que indicam soluções diferenciadas. ${ }^{24}$

A ponderação não consiste em incidir a premissa maior (lei) sobre a premissa menor (caso concreto), tal como ocorre com a subsunção; aqui, cada elemento e peculiaridade do caso concreto será levado em consideração para que, ao final, tenha-se obtido o melhor resultado para aquele caso específico.

Nos Estados Unidos, o direito à liberdade de expressão é tido como direito fundamental preferencial, se sobrepondo, em quase todas as situações, aos demais direitos fundamentais, posto que o direto à honra é

\footnotetext{
${ }^{23}$ É a ação ou efeito de subsumir, isto é, incluir (alguma coisa) em algo maior, mais amplo. Como definição jurídica, configura-se a subsunção quando o caso concreto se enquadra à norma legal em abstrato. É a adequação de uma conduta ou fato concreto (norma-fato) à norma jurídica (normatipo). É a tipicidade, no direito penal; bem como é o fato gerador, no direito tributário. In. http://www.direitonet.com.br/dicionario/exibir/883/Subsuncao

${ }^{24}$ BARROSO, Luis Roberto. Op. Cit.
} 
um limite interno à liberdade de expressão, ou seja, decorre de sua própria natureza como direito fundamental ${ }^{25}$. Quando em conflito com algum direito fundamental seu escopo já está definido, e suas limitações préestabelecidas, tornando sua análise facilitada, pois a jurisprudência deve apenas verificar se aquele caso específico se enquadra nas limitações já préconhecidas. Diferente do que acontece nos Estados Unidos, a Espanha estabelece em sua Constituição, no art. 20.4, o direito à honra como um limite às liberdades de expressão e informação, e seu processo de resolução de conflitos é feito através de uma ponderação posterior, com o intuito de verificar o direito fundamental que deverá prevalecer na situação específica, técnica que se assemelha à utilizada por tribunais brasileiros.

Através da análise de casos a serem apresentados neste trabalho, verifica-se que a jurisprudência brasileira encontra dificuldades quando da presença de conflito entre direitos fundamentais. A falta de limites aos direitos fundamentais pré-estabelecidos e consequentemente conhecidos de antemão pela doutrina e partes do conflito faz com que tenhamos uma jurisprudência não uniformizada a respeito dos mesmos, e isso é extremamente prejudicial em um estado de direito democrático onde a regra deveria ser a liberdade de expressão, e sua limitação, uma exceção.

\footnotetext{
${ }^{25}$ CHEQUER, Cláudio. A Liberdade de Expressão como Direito Fundamental Preferencial Prima Facie (análise crítica e proposta de revisão ao padrão jurisprudencial brasileiro).Rio: Editora: Lumen Juris. 2011. p. 62
} 


\section{CAPITULO II - O HUMOR COMO MANIFESTAÇÃO DA LIBERDADE DE EXPRESSÃO}

\subsection{As diferentes manifestações da linguagem humorística: piada, ironia, imitação, e paródia}

Uma boa piada é aquela pensada e escrita para que desperte na sua plateia o riso, e isso é feito através do uso de recursos da linguagem humorística. Ao contrário do cômico, o humor está na linguagem, resultado de desvios em determinados padrões semânticos, estruturais e de pensamento. Sírio Possenti afirma que esses recursos humorísticos consistem em permitir a descoberta de outro sentido, de preferência inesperado, frequentemente distante daquele que é expresso em primeiro plano e que, até o desfecho da piada, parece ser o único possível ${ }^{26}$. O riso seria consequência, portanto, da quebra da previsibilidade.

Diversos estudos discorrem sobre o que provoca o riso, dentre os quais os de Henri Bergson ganham destaque. Em $O$ Riso, Bergson estabeleceu o que seria necessário para tornar algo cômico, a saber: a humanidade, a insensibilidade e a sociabilidade ${ }^{27}$. Bergson explica que só rimos de algo, até mesmo uma paisagem, animal ou um objeto porque identificamos inconscientemente, nessas coisas, algo de humano, seja devido à "semelhança com o homem, à marca que o homem lhe imprime ou ao uso que o homem lhe dá". Além disso, esclarece que é necessária uma certa "insensibilidade" para com a questão, de certa forma, a pessoa deve estar em um momento de tranqüilidade, ou como o autor mesmo explica: "a comicidade só poderá produzir comoção se cair sobre uma superfície d'alma serena e tranqüila." ou quando afirma que "o riso não tem maior inimigo que a emoção.”.

\footnotetext{
${ }^{26}$ POSSENTI, Sírio. Humor, Lingua e Discurso. 1a edição. São Paulo: Contexto, 2010.p. 61

${ }^{27}$ BERGSON, Henri. $O$ Riso. p. 4-5. Disponível em: http://minhateca.com.br/livros_gratis_BR/BERGSON*2c+Henri.+O+Riso,68366.pdf. Acesso em: 02 de out. de 2014.
} 
O autor nos mostra que não há comicidade fora do que é propriamente humano e que, para ser engraçado, a participação de uma outra inteligência que dele compartilhe é imprescindível, já que "o nosso riso é sempre o riso de um grupo". Bérgson tece a ideia de que o cômico decorre do emprego do sentido figurado de alguma expressão:

Obteremos efeito cômico se fingirmos entender uma expressão no sentido próprio quando ela é empregada no sentido figurado. Ou ainda: Quando nossa atenção se concentra na materialidade de uma metáfora, a ideia expressa se torna cômica.

A linguagem pode ser objeto do riso quando o autor é habilidoso o bastante para explorar as "inúmeras possibilidades criativas de manipulação dela" ${ }^{28}$. Existem várias técnicas que resultam em diferentes manifestações humorísticas, quais sejam: piada, ironia, imitação e a paródia.

A piada consiste em uma breve história, de final engraçado e às vezes surpreendente, muito usada no cotidiano. Normalmente, a piada consiste em duas fases: uma introdução genérica e um final surpreendente, que entra em choque com o desenvolvimento e, pela surpresa causada no ouvinte, provoca o riso ${ }^{29}$.

Esse recurso normalmente tem como objeto situações do cotidiano do seu ouvinte, porém situadas fora de seu contexto usual, provocando o riso. Para Possenti, o interessante das piadas é que elas quase sempre versam sobre temas controversos, e operam fortemente com estereótipos ${ }^{30}$. Isto é comprovado quando estudamos os diversos tipos de piadas que abordam loiras, políticos, piadas étnicas, sobre portugueses etc. Essas piadas contam uma história hipotética, ressaltando as características do estereótipo de cada sujeito.

\footnotetext{
28 JORGE, Carlos Leonardo Weber. ONDE ESTÁ A GRAÇA? - O HUMOR SEGUNDO BERGSON EM CONTOS DE MARK TWAIN. Disponível em, http://www.letras.ufpr.br/documentos/graduacao/monografias/ss-2009/Onde-graca.pdf. Acesso em: 02 de out. de 2014

${ }^{29}$ WIKIPEDIA. Piada. Disponível em http://pt.wikipedia.org/wiki/Piada. Acesso em: 02 de out. de 2014.

${ }^{30}$ POSSENTI, Sírio. Humores da língua. Campinas: Mercado de Le- tras. 2000. Disponível em: http://www.scielo.br/scielo.php?pid=S0102-44502001000200010\&script=sci_arttext. Acesso em: 02 de out. de 2014.
} 
Estudando essas piadas podemos entender muito dos costumes e valores inseridos em uma sociedade. Nas piadas, os personagens são retratados sempre da mesma forma, as loiras sempre burras, os políticos sempre ladrões e os advogados sempre interesseiros. Podemos afirmar, portanto, que as piadas fornecem um dos melhores retratos dos valores e problemas de uma sociedade ${ }^{31}$.

A piada está presente em textos que operam com ambigüidades, através do duplo sentido, que, por sua vez, dependem fortemente de fatores circunstanciais.

A ironia é um instrumento que consiste em dizer o contrário daquilo que se pensa, estabelecendo uma distância intencional entre aquilo que dizemos e aquilo que realmente pensamos. É utilizada com o objetivo de denunciar, criticar ou censurar alguém ou alguma situação, e normalmente feita em tom crítico, facilmente percebida pelo tom de voz empregado pela pessoa que a utiliza, quando feita oralmente. O que torna a ironia tão característica é a técnica de subverter o símbolo que, a princípio, representa. A ironia utiliza-se como uma forma de linguagem pré-estabelecida para, a partir e de dentro dela, contestá-la ${ }^{32}$.

Imitação é um comportamento avançado pelo qual um indivíduo observa e replica outro. Quando a imitação tem o objetivo de provocar o riso, é feita como forma de zombar de alguém ou alguma característica que aquela pessoa possuí ${ }^{33}$.

Essa técnica, todavia, não é somente manifestação do humor, mas pode ser empregada também como uma forma de aprendizagem por observação que leva ao desenvolvimento de tradições, línguas, práticas etc.

\footnotetext{
${ }^{31}$ POSSENTINI, Sírio. $O$ humor $e$ a língua. Disponível em http://aescritanasentrelinhas.com.br/2009/02/15/o-humor-e-a-lingua/. Acesso em: 02 de out. de 2014.

${ }^{32}$ WIKIPEDIA. Ironia. Disponível em http://pt.wikipedia.org/wiki/Ironia. Acesso em: 02 de out. de 2014.

${ }^{33}$ WIKIPEDIA. Imitação. Em http://pt.wikipedia.org/wiki/Imitação. Acesso em: 02 de out. de 2014.
} 
Por fim, a paródia é uma interpretação cômica de alguma composição literária, que freqüentemente utiliza outra técnica, a ironia, e o deboche para se materializar. Ela é um forma de imitação que utiliza a ambigüidade e o duplo sentido para um releitura da obra. O objetivo da paródia é adaptar a obra original a um novo contexto, dando à obra um lado mais despojado ${ }^{34}$.

A Lei de Direitos Autorais (Lei No. 9.610) prevê a imitação, e diz que "são livres as paráfrases e paródias que não forem verdadeiras reproduções da obra originária nem lhe implicarem descrédito" ${ }^{135}$.

Os métodos acima mencionados são expressões artísticas que, com base no princípio da livre manifestação do pensamento e da liberdade de expressão artística e intelectual, podem ser utilizados livremente. Contudo, como qualquer liberdade, sua aplicação encontra limites no mundo jurídico, podendo ser tido como ofensa a direito da personalidade.

\subsection{O humor como veículo de informação}

A expressão "antes rir do que chorar" é amplamente utilizada em situações do cotidiano, e possui uma conotação melancólica. A expressão demonstra que, no meio de tantos males e catástrofes recorrentes no mundo inteiro, amplamente divulgadas com a ajuda da mídia, o homem precisa rir de tragédias como forma de superação.

Seguindo essa linha de raciocínio, o autor George Minois afirma que a concepção do riso moderna e racional aparece em um momento em que as ciências humanas mostram a fragilidade e complexidade do ser humano ${ }^{36}$.

O humor se torna uma possibilidade de auxiliar o leitor a suportar a própria dor do cotidiano. Essa técnica se tornou cada vez mais popular e utilizada pelos veículos de comunicação; em todos os jornais vemos

\footnotetext{
${ }^{34}$ Paródia. Disponível em http://pt.wikipedia.org/wiki/Paródia. Acesso em: 02 de out. de 2014.

${ }^{35}$ Art. 47 da Lei número 9.610.

${ }^{36}$ MINOIS, George. História do riso e do escárnio. Tradução: Maria Helena O. Ortiz Assumpção. São Paulo: Editora UNESP,2003, p. 633.
} 
charges, notícias com tom humorístico, programas humorísticos, entre outros.

O apelo humorístico ao veicular uma notícia se tornou cada vez mais comum, uma vez que a linguagem humorística é mais simples, de fácil compreensão e facilita a assimilação da informação, captando uma maior audiência.

Dentre os meios de comunicação a utilizar a linguagem humorística, a televisão foi pioneira, através de programas humorísticos, como o Monty Phyton, grupo de humor britânico que implementaram um novo estilo de texto e representação, marcado pelo estilo anárquico e pautado pelo completo surrealismo das cenas. O programa originário, Monty Python's Flying Circus, era composto por pequenas cenas de humor e rápidas animações. $\mathrm{O}$ grupo influenciou sua geração e serviu de base para diversos outros programas que surgiriam posteriormente, como South Park e Saturday Night Live. A palavra pythonesque, oriunda do nome do grupo, está presente no dicionário da língua britânica para indicar algo surreal ou absurdo, e o estilo de humor usado pelo grupo. ${ }^{37}$

Aqui no Brasil, podemos mencionar o programa Cabaré da Barata, que era composto por diversas cenas humorísticas protagonizadas por fantoches que representavam os políticos da época como José Sarney, Jânio Quadros, e Tancredo Neves, que aparecia como um anjo apos a sua morte, em $1985^{38}$. Outros programas humorísticos populares no Brasil eram a $T V$ Pirata, que também era composto por jovens atores que ironizavam a realidade brasileira, satirizando a programação da TV da época, e o Casseta \& Planeta, cujos personagens ironizavam a realidade do país e também

\footnotetext{
${ }^{37}$ Significado de pythonesque. Disponível em: http://www.oxforddictionaries.com/definition/english/Pythonesque. Acesso em: 02 de out. de 2014.

38 SANCHOTENE, Carlos Renan Samuel. Mídia, humor e política: a charge da televisão. Disponível http://books.google.com.br/books?id=RDrcjEso6N4C\&pg=PA56\&lpg=PA56\&dq=cabaré+do+bar ata + artigos + humor\&source $=$ bl\&ots $=$ Dqxn0bLvP\&sig=_3PT4eoTw_CzdF8dBvEBuuDulZ0\&hl=pt$\mathrm{BR} \& \mathrm{sa}=\mathrm{X} \& \mathrm{ei}=8 \mathrm{DR} \overline{\mathrm{Y}} \mathrm{V}$ OqsMoObgwSSvoHYDw\&redir_esc $=\mathrm{y} \# \mathrm{v}=$ onepage $\& \mathrm{q}=$ cabaré $\% 20 \mathrm{do} \% 20$ barata\%20artigos\%20humor\&f=false. Acesso em: 20 de out. de 2014.
} 
imitavam figuras públicas, como artistas e políticos. Com o passar do tempo, várias outras emissoras passaram a incluir quadros humorísticos em suas programações.

Apesar de ser recorrente, não é todo assunto que permite o uso de uma linguagem humorística, como casos de morte, desastre naturais e acidentes. É uma linguagem que deve ser reservada para assuntos de interesse público e que, de uma certa forma, já se tornaram "piada" entre a população pela falta de seriedade, como a política no Brasil.

Atualmente, o programa $C Q C$, exibido pela Band, é um exemplo de que jornalismo e humor podem informar e ao mesmo tempo entreter. $\mathrm{O}$ programa é famoso por aparecer no Congresso Nacional, onde os repórteres fazem perguntas indiscretas aos parlamentares que, provavelmente, muitos dos telespectadores gostariam de fazer. Obviamente, a ousadia incomodou muitos dos parlamentares, tanto que, em 2008, a equipe foi proibida de realizar filmagens no órgão. Somente puderam retornar devido à muita pressão do público, através do movimento intitulado "CQC no Congresso".

O programa cumpre a função do jornalismo humorístico, uma vez que através da ironia, sarcasmo e perguntas de duplo sentido, convidam o público a ter uma visão crítica do que é apresentado. Essas técnicas colocam os entrevistados "contra a parede", provocando as mais diversas reações e muitas vezes os "desmascarando".

O jornalismo humorístico não está apenas atrelado a programas humorísticos, mas também se apresenta no caso do jornalismo impresso, sempre atrelado ao jornalismo de opinião pelos teóricos ${ }^{39}$. Alguns exemplos são o José Simão, cronista do cotidiano da Folha de S. Paulo, e o jornalista Millôr Fernandes, falecido em 2012, e incluímos aqui todos os chargistas e cartunistas dos jornais e revistas. Nenhum deles está ali como humorista, mas como jornalistas que têm o dever de informar, só que utilizando

\footnotetext{
${ }^{39}$ PIRES, Paulo Sérgio. Difíceis delimitações no "jornalismo humorístico". In: Observatório da Imprensa. Disponível em: http://200.169.104.103/news/view/dificeis_delimitacoes_no_jornalismo_humoristico. Acesso em: 02 de out. de 2014.
} 
técnicas da linguagem humorística para fazer valer seu ponto de vista.

No Brasil, o jornalismo humorístico ainda tenta firmar seu lugar como jornalismo eficaz e sério. Enquanto aqui os políticos fogem de perguntas embaraçosas, como no caso dos parlamentares entrevistados pelo CQC, nos Estados Unidos, essa modalidade jornalística é mais do que aceita, é respeitada.

O humor de Saturday Night Live se tornou parte importante em uma das principais campanhas eleitoras do século, ao imitar a candidata a VicePresidência dos Estados Unidos, Sarah Palin, que foi sucesso instantâneo. Quem ficou responsável por imitar a governadora do Alaska foi Tina Fey, cuja personagem se tornou mais popular do que a própria Sarah. Ficou claro com seu sucesso que o jornalismo humorístico pode ser um aliado eficiente, pois "colocou Sarah no mapa", como dizem os americanos. Ao decidir participar do programa, que foi ao ar no dia 18 de outubro de $2008^{40}$, Sarah se tornou celebridade além de figura pública, e o programa teve sua maior audiência desde 1994. Nos Estados Unidos, o humor é visto como uma forma amena e mais suave de fazer críticas, e evitando ofensas à personalidade. A popularidade da personagem e do programa fez com que muitos se interessassem mais pela candidata e republicana e, conseqüentemente, pela política no país, conforme estudo de uma professora de Comunicação da Universidade de Delaware, Danna Young ${ }^{41}$.

Já o Presidente Barack Obama, na época de eleição em 2012, fez questão de ser entrevistado por Jon Stewart, famoso apresentador do talkshow americano The Daily Show. O show é definido como Comédia Política. A entrevista foi considerada pelo Secretário de Imprensa da campanha de Obama, Jay Carny, como a mais difícil do candidato durante a

\footnotetext{
40 Participação de Sarah Palin em Saturday Night Live. Disponível em: http://edition.cnn.com/2008/SHOWBIZ/TV/10/18/palin.snl/. Acesso em: 03 de nov. De 2014.

${ }^{41}$ Young estudou as audiências dos programas de comédia de late-night e de sátira política e concluiu que os telespectadores desses programas exibiam um maior nível de familiariedade com as notícias do dia do que as pessoas que não os viam. Particularmente os do Daily Show, constatou a investigadora - "sabem mais de política, participam mais no processo democrático e lêem mais sobre assuntos domésticos e internacionais do que o americano médio", refere. Disponível em: http://www.publico.pt/destaque/jornal/o-humor-foi-um-veiculo-de-informacao-na-campanha-maissatirizada-de-sempre-282285. Acesso em: 02 de out. de 2014.
} 
campanha de 2012, com perguntas que colocaram o Presidente contra a parede, enquanto os telespectadores se divertiam. Diferente do que acontece com políticos no Brasil, ambos (Sarah Palin e Barack Obama) abraçaram a oportunidade de participar de programas populares que usam o humor como sua maior arma.

A linguagem humorística também pode ser útil na área jurídica, como demonstrou um Juiz da $1^{\mathrm{a}}$ Vara de Execuções Penais de Belém, Cláudio Rendeiro, que criou um personagem com o intuito de levar informações de utilidade pública a todo o Estado. O juiz, locutor do programa de rádio cujo nome é Escuta, mano, meu recado! $!^{42}$, que vai ao ar diariamente nas rádios Cultura FM em Belém e em cidades no interior do Pará, e tem duração de 1 minuto, onde o personagem Epaminondas Gustavo, inspirado no público-alvo da rádio, aborda temas do Judiciário que refletem diretamente no cotidiano da população. Utilizando uma linguagem regional, acessível e humorística, o juiz faz com que assuntos jurídicos pouco discutidos e conhecidos pela sua audiência sejam abordados de forma simples e facilmente compreendidos. Através de uma linguagem mais simples o juiz consegue levar à população informações acerca de seus direitos garantidos pelo judiciário.

É possível que a linguagem humorística seja uma importante aliada na hora de levar informações à população, o que tem acontecido de forma progressiva e cautelosa no Brasil; no entanto, não é uma questão pacífica e ainda encontra muita resistência na prática.

\subsection{O Humor como crítica}

O humor é muitas vezes utilizado como uma forma mascarada de criticar e uma tentativa de proteger seu autor das conseqüências negativas que isso poderia gerar. A linguagem humorística com o intuito de criticar

\footnotetext{
${ }^{42}$ Personagem de humor criado por juiz dissemina informações sobre o Judiciário. Disponível em: http://www.cnj.jus.br/noticias/cnj/29581-personagem-de-humor-criado-por-juiz-disseminainformacoes-sobre-o-judiciario. Acesso em: 02 de out. de 2014.
} 
deve ser usada com cautela, sendo possível a formulação de juízos pejorativos, visto que ninguém é obrigado a tecer somente elogios, mas isso não permite ao crítico fazer uso de expressões injuriosas e que constituem ofensa à honra da vítima ${ }^{43}$.

O direito de crítica, reflexo do direito de manifestação do pensamento, se concretiza através da emissão de um juízo de valor a respeito de uma pessoa ou informação, seja ele positivo ou negativo. No jornalismo impresso, normalmente o humor comporta uma opinião. Cronistas, chargistas, cartunistas e caracturistas dos jornais e revista não têm como função principal o humor, não são humoristas, mas sim, jornalistas.

No entanto, o poder de crítica que carrega uma charge ou caricatura pode ter uma influencia muito superior a um simples artigo. A charge pode ser um dos instrumento mais eficientes para a crítica, e um alternativa inteligente ao jornalismo comum.

Charge é um espécie de ilustração que tem por finalidade satirizar, por meio de uma caricatura, algum acontecimento ou pessoas. A charge é uma crítica político-social, muito utilizada no Brasil, onde o artista expressa graficamente sua visão sobre determinadas situações cotidianas através do humor e da sátira, denunciando situações do cotidiano que às vezes passam despercebidas pelo leitor ${ }^{44}$. A charge possuí um alcance muito maior sobre a sua audiência do que um simples editorial, uma vez que não é necessário profundo conhecimento do assunto para entender aquilo que está sendo projetado na charge. É necessário, no entanto, um conhecimento do que está acontecendo em sua volta, para ser perceptível o caráter de ambigüidade que a charge carrega. Como exemplo, tomemos a charge a seguir:

\footnotetext{
${ }^{43}$ JUNIOR, Vidal Serrano Nunes. A Proteção Constitucional da Informação e o Direito à Crítica Jornalística. Coordenação; Hélio Bicudo. Sao Paulo: FTD, 1997. p. 96.

${ }^{44}$ WIKIPEDIA. Charge. Disponível em: http://pt.wikipedia.org/wiki/Charge. Acesso em 02 de out. de 2014.
} 


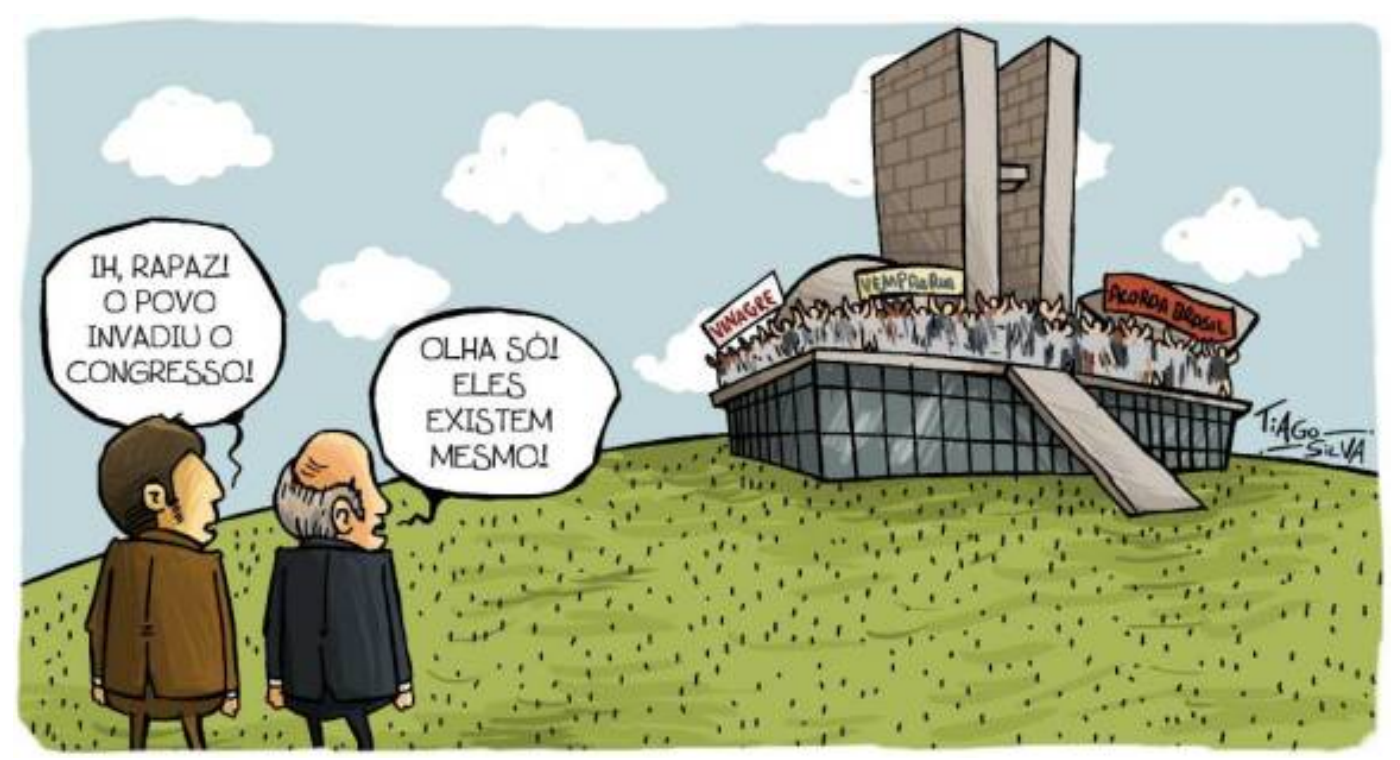

https://www.facebook.com/tiagosilvacartoons. Acesso em 02 de out. de 2014.

Na charge sobre análise, o autor faz menção aos protestos ocorridos em 2013, especificamente ao episódio ocorrido no dia 17 de junho de 2014, em que um grande grupo de manifestantes rompeu o cordão de isolamento da Polícia Militar e ocuparam a marquise do Congresso Nacional onde ficam as cúpulas da Câmara e do Senado, em Brasília. Acompanhando esta imagem, dois homens, presumidamente políticos, que questionam o aparecimento do povo como algo inédito, nos remetendo à ideia de que os políticos não governam para o povo e nem sequer sabem de sua existência.

Arnaldo Angeli Filho, comumente chamado somente de Angeli, é um dos cartunistas mais conhecidos do Brasil, responsável por inúmeras charges que denunciam a corrupção no país, dentre elas, a "Assim Caminha a Humanidade" (a baixo) em que aparecem 6 quadrinhos com os expresidentes do Brasil, da época da ditadura militar até o ex-presidente Lula, e cada um deles com uma fala, como podemos ver abaixo. A frase, repetida por todos, é a de que "não existe corrupção em órgãos públicos", nos fazendo pensar no problema institucional que é a corrupção, presente em todos os governos, independente do Presidente em atuação, e sempre negada por todos eles. 

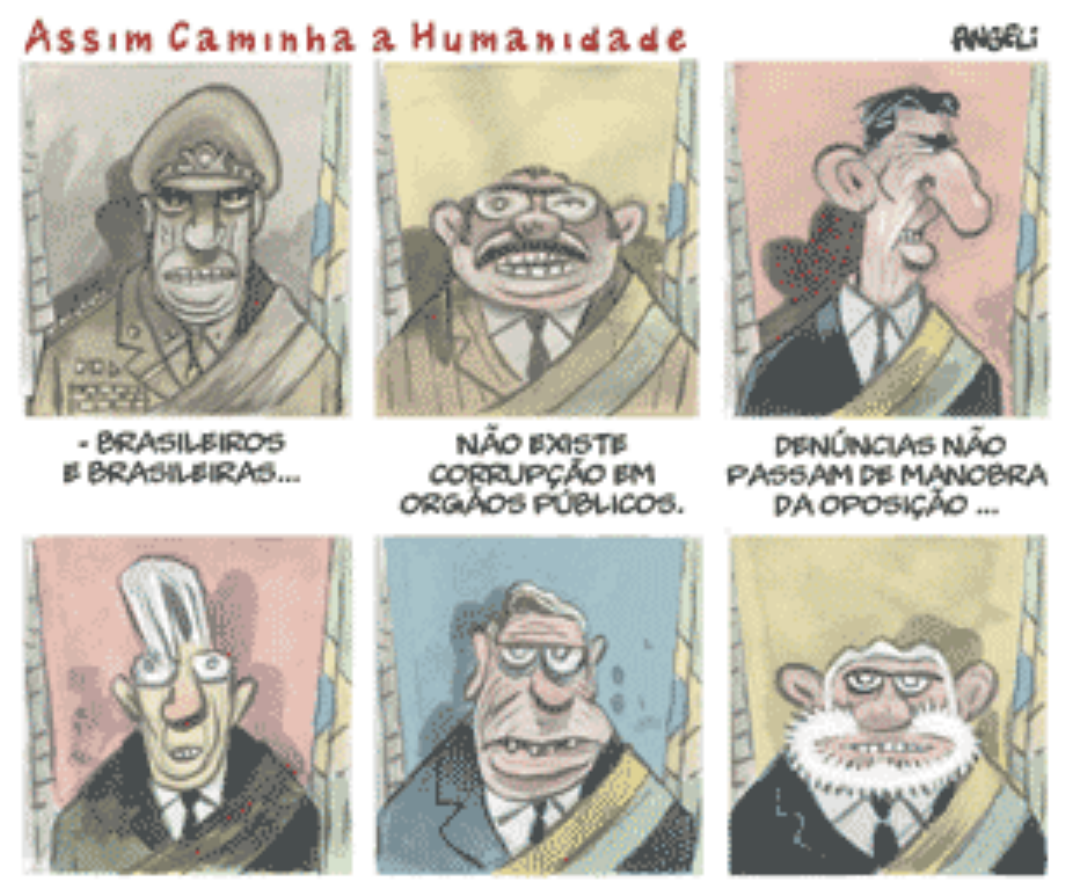

NA TENTATIVADE DASESTABILIZAR

-. EABALAROS

ALICERCES DA

DEMOCRACIA.

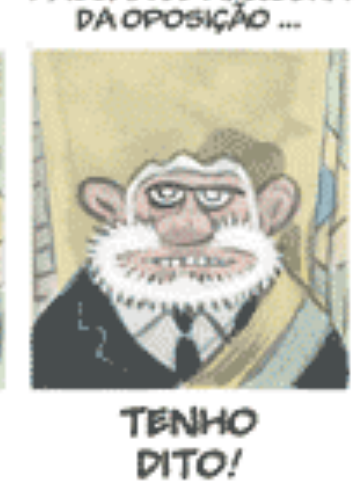

https://http://www2.uol.com.br/angeli/?imagem=335\&total=335. Acesso em 02 de out. de 2014.

A crítica humorística, no entanto, não se restringe às charges. A internet e o surgimento das redes sociais possibilitou à população expressar sua opinião e alcançar um maior número de pessoas, culminando na criação de diversos blogs, páginas e canais de humor. Um deles ganha maior destaque, o canal de humor Porta dos Fundos, notório pelos esquetes de humor, em sua maioria criticando e satirizando temas controversos como política e religião, e gerando muita polêmica. De acordo com o próprio web site, esse é o objetivo, "(...) a PORTA DOS FUNDOS vive em função de permanecer aberta e mostrando o que a sala de estar do entretenimento não permite. Sejam bem-vindos." ${ }^{45}$

Um dos vídeos que criaram mais polêmica foi o especial de Natal, onde se discutia a real paternidade de Jesus e uma "carteirada" dada pelo "filho de Deus" para conseguir uma mesa na Santa Ceia. Tal vídeo virou

\footnotetext{
${ }^{45}$ Definição da PORTA DOS FUNDOS. Disponível em: http://www.portadosfundos.com.br/sobre/. Acesso em: 02 de out. de 2014.
} 
objeto de uma verdadeira guerra santa na Internet, alguns afirmando até que se tratava de intolerância religiosa por parte dos humoristas.

$\mathrm{O}$ vídeo causou tanto furor que o diretor da Associação Nacional Provida Família afirmou que "O riso não é condenável, em si, mas quando utilizado como arma de perversão sexual e afronta religiosa, torna-se abominável", afirmando que o humor é permitido, mas somente nos limites determinados pela sociedade e desde que não ofenda ou diga respeito a assuntos delicados. Essa, como inúmeras outras instituições religiosas, colocaram o respeito a sentimentos religiosos acima do direito à liberdade de expressão, entendo que este, para ser aceito, deve se submeter àquele.

Um outro vídeo do grupo causou revolta em um grupo de policiais militares do Rio de Janeiro, que fizeram ameaças ao humorista Fábio Porchat, um dos principais atores do grupo. O vídeo, intitulado Dura, em uma clara crítica aos policiais corruptos, mostra dois cidadãos comuns dando um sermão em dois policiais militares que estão dormindo dentro de uma viatura.

Um policial militar, através do Blog do Soldado, expressando o sentimento da corporação, teceu comentários negativos ao Fábio Porchat, um dos atores do vídeo:

Você não sabe o ódio que despertou em todos nós policiais militares, ao postar essa $b .$. de vídeo. Humilhou a todos os policiais militares e por isso estamos rebatendo sua crítica de mau gosto. ${ }^{46}$

Importante notar a reação que o vídeo causou nos policiais, um deles chegando a afirmar que "Por isso a Polícia não presta pra vocês", como se a Polícia estivesse ali para "prestar" somente para poucos. Ao invés de se preocuparem com o problema apresentado que, infelizmente, faz parte do cotidiano do brasileiro, se preocupam com um vídeo de humor e é ai que está o verdadeiro problema.

\footnotetext{
${ }^{46}$ Disponível em: http://blogdosoldadopm.blogspot.com.br. Acesso em 20 de setembro de 2014.
} 
Através da ironia, pode-se provocar o leitor a ter um olhar mais crítico sobre alguma situação. Tanto no grupo Porta dos Fundos, quanto no trabalho dos chargistas e cartunistas, percebemos muito mais do que um simples desejo de provocar o riso, transparece uma preocupação social. O humor deve ir além da diversão; deve ser também, e muitas vezes é, uma forma de manifestar a indignação contra injustiças sociais. $O$ seu uso permite que sejam ditas "verdades" mais claramente percebidas do que se ditas por qualquer outro meio. 


\section{CAPITULO III - OS PRINCÍPIOS LIMITADORES E O CONFLITO NO JUDICIÁRIO}

\subsection{Considerações gerais acerca dos limites à liberdade de expressão}

No século XVIII, os direitos fundamentais eram tidos como absolutos e ilimitados, ideia que se originava de um conceito racionalista do Direito Natural, onde qualquer restrição aos direitos fundamentais era entendida como contrária à natureza humana. ${ }^{47}$

Tal ideia, de difícil aceitação atualmente, encontra um exemplo na Declaração de Direitos de Virgínia, de 12 de junho de 1776, que estabelecia em sua $12^{a}$ Seção que “[...] a liberdade de imprensa é um dos grandes baluartes da liberdade e não pode ser restringida jamais, a não ser por governos despótico". 48

Esse entendimento não perdura nos dias atuais, e foi superado pela visão de que os direitos fundamentais fazem parte de uma rede de direitos que precisam coexistir entre si, caso contrário se tornariam ineficazes. ${ }^{49}$

A noção de que os direitos fundamentais podem sofrer limitações é pacífica, tendo sido inclusive evidenciado no art. 29 , parágrafo $2^{\circ}$ da Declaração Universal dos Direitos Humanos, quando estabelece que:

(...) no exercício de seus direitos e liberdades, todo o homem estará sujeito apenas às limitações determinadas pela lei, exclusivamente com o fim de assegurar o devido reconhecimento e respeito dos direitos e liberdades de outrem e de satisfazer as justas exigências da moral, da ordem pública e do bem-estar de uma sociedade democrática. ${ }^{50}$

\footnotetext{
${ }^{47}$ CHEQUER, Cláudio. Op. Cit. p. 43.

${ }^{48}$ No original: "That the freedom of the press is one of the great bulwarks of liberty, and can never be restrained but buy despotic governments“. Disponível em: http://www.dhnet.org.br/direitos/anthist/dec1776.htm. Acesso em: 02 de out. de 2014.

${ }^{49}$ RENUCCI, Jean-François. Droit européen dês droits de l'homme. Paris: L.G.D.J.,1999, p. 369. apud. CHEQUER, Cláudio. Op Cit.. p. 44

${ }^{50}$ CHEQUER, Cláudio. Op. Cit., p. 44
} 
A Constituição brasileira prevê a possibilidade de direitos fundamentais sofrerem restrições ${ }^{51}$, mas esta decorre da própria sistemática jurídica na qual os direitos estão inseridos. ${ }^{52}$ Os direitos fundamentais não foram idealizados para agir independentemente, mas sim em conjunto, para que fossem aplicados harmoniosamente com os demais direitos fundamentais e normas constitucionais.

Os direitos fundamentais estariam sujeitos, portanto, às limitações externas $^{53}$, principalmente àquelas provenientes de conflitos com outros direitos fundamentais. Devido ao seu caráter amplo e universal, sendo aplicado da mesma forma e conteúdo a todos, a possibilidade de conflito entre os direitos fundamentais é inevitável, e acontece com freqüência. O direito à liberdade de expressão, é claro, não é isento a tais conflitos, e encontra nos direitos à honra e à imagem seus principais limitadores.

Alguns autores, como Luís Roberto Barroso, Fábio Leite e Cláudio Chequer, defendem a chamada preferred position da liberdade de expressão quando manifestada através da liberdade de informação, uma vez que estaria inserida na seara da liberdade de imprensa ${ }^{54}$. A ideia de posição

\footnotetext{
${ }^{51}$ Essa seria, segundo Cláudio Chequer, a Teoria Interna dos Limites dos Direitos Fundamentais, onde a Constituição já determina, previamente e de maneira definitiva, o conteúdo de todos os direitos fundamentais, fixando ainda todos os seus limites. O conteúdo de todo direito fundamental já viria limitado pela própria Constituição, em razão da própria natureza de cada direito e de sua função social. CHEQUER, Cláudio. Op. Cit., p. 45

Seguem alguns exemplos previstos em alguns dos incicos do art. $5^{\circ}$ da CF: "IV - é livre a manifestação do pensamento, sendo vedado o anonimato; XII - é inviolável o sigilo da correspondência e das comunicações telegráficas, de dados e das comunicações telefônicas, salvo, no último caso, por ordem judicial, nas hipóteses e na forma que a lei estabelecer para fins de investigação criminal ou instrução processual penal; XIII - é livre o exercício de qualquer trabalho, ofício ou profissão, atendidas as qualificações profissionais que a lei estabelecer;“".

52 SOARES, Ana Carolina Trindade. Dos limites às restrições aos Direitos Fundamentais. Disponível em: <http://amplodireito.com.br/noticia/60/artigos/2012/06/08/dos-limites-asrestricoes-aos-direitos-fundamentais $>$. Acesso em 27 de out. de 2014.

53 A Teoria Externa dos Limites dos Direitos Fundamentais baseia-se na noção de que a identificação do âmbito de proteção de um direito fundamental exigiria duas fases de raciocínio. A primeira consistiria em identificar o conteúdo protegido de um direito fundamental, que seria bem amplo. Posteriormente, haveria uma necessidade de promover uma harmonização do conteúdo deste direito fundamental com os demais, chegando-se, então, ao conteúdo definitivo do direito fundamental: a identificação das situações que podem considerar-se definitivamente amparadas por um direito fundamental. CHEQUER, Cláudio. Op. Cit., p. 49

54 BARROSO, Luís Roberto. Op. Cit. "Além das expressões liberdade de informação e de expressão, há ainda uma terceira locução que se tornou tradicional no estudo do tema e que igualmente tem assento constitucional: a liberdade de imprensa. A expressão designa a liberdade reconhecida (na verdade, conquistada ao longo do tempo) aos meios de comunicação em geral
} 
preferencial da liberdade de expressão é muito utilizada nos Estados Unidos, e reconhecida pelo Tribunal constitucional espanhol ${ }^{55}$ e pelo Tribunal constitucional federal alemão ${ }^{56}$, onde há uma "doutrina dos direitos fundamentais preferenciais" ${ }^{, 57}$ e é aplicada uma hierarquia entre os direitos fundamentais. Essa hierarquia funciona de tal maneira que, existindo uma controvérsia entre dois direitos fundamentais, aquele considerado hierarquicamente superior gozaria de uma posição preferencial em relação ao direito oposto.

Essa hierarquia seria apenas primae facie, de acordo com Cláudio Chequer, pois nada impede que essa posição preferencial seja invertida diante das circunstancias do caso concreto ${ }^{58}$.

A liberdade de expressão é um dos direitos considerados pelos americanos como preferenciais e possuí uma posição hierarquicamente superior aos demais direitos fundamentais. Essa preferência estaria justificada, segundo Cláudio Chequer, em razão dos seguintes "fundamentos filosóficos":

a) a importância da liberdade de expressão para a descoberta da verdade; b) a liberdade de expressão vista como um aspecto de autossatisfação (selffulfilment); c) a liberdade de expressão como forma de garantir uma participação efetiva a democracia; e, d) suspeita do governo, já que os governos

\footnotetext{
(não apenas impressos, como o termo poderia sugerir) de comunicarem fatos e ideias, envolvendo, desse modo, tanto a liberdade de informação como a de expressão."

${ }^{55}$ SERRA, Lluis de Carrera, Régimen juridico de la Información, 1996, apud Porfirio Barroso e María del Mar López Talavera, La libertad de expresión y sus limitaciones constitucionales, 1998, p. 48: "La jurisprudencia constitucional otorga a la libertad de expresión o de información un carácter preferente sobre los demás derechos fundamentales, como son el derecho al honor, la intimidad y la propia imagen. De manera que si la libertad de expresión se practica legítimamente - porque no se utilizan expresiones formalmente injuriosas -, el derecho al honor cede ante ella. $\mathrm{O}$ si la libertad de información se ejerce con noticias que son de interés público por su contenido o por referirse a una persona de relevancia pública, ha de protegerse frente al derecho al honor". apud BARROSO, Luís Roberto. Op. Cit.

${ }^{56}$ FARIAS, Edilsom Pereira de. Colisão de direitos - a honra, a intimidade, a vida privada e a imagem versus a liberdade de expressão e informação, 2000, p. 178: "O Bundesverfassungsgericht (Tribunal Constitucional Alemão), especialmente a partir da sentença do caso Lüth, também estabelece uma preferência pela liberdade de expressão e informação ao considerá-la como direito individual indispensável para o regime democrático". Apud BARROSO, Luís Roberto. Op. Cit.

${ }^{57}$ CHEQUER, Cláudio. Op. Cit. P. 96

${ }^{58}$ Ibid.
} 
têm fortes razões para ter medo dos impactos das ideias, sendo, pois, naturalmente tentados a repreende-las. ${ }^{59}$

Luís Roberto Barroso entende que a posição preferencial do direito à liberdade de expressão decorre da concepção de que este serve de fundamento para o exercício de outras liberdades ${ }^{60}$. O Ministro chega à conclusão de que o interesse público na divulgação de informações é presumido e, por conseguinte, não será limitado, salvo em situações excepcionalíssimas, as quais chama de "situações-limite (...) de quase ruptura do sistema" ${ }^{\prime 61}$

Fábio Leite aponta que essa doutrina ainda é pouco conhecida no Brasil, o que se justifica pela noção geral de que os conflitos entre liberdade de expressão e direito à honra podem ser facilmente resolvidos através de uma harmonização, e que não demandaria uma solução drástica como a de dar a um direito fundamental preferência sobre outro. $\mathrm{O}$ autor defende a posição preferencial da liberdade de expressão principalmente em conflitos com o direito à honra, uma vez que a importância do conteúdo da liberdade de expressão é diretamente proporcional ao tom crítico usado. Quanto mais forte for o tom crítico acerca do objeto divulgado, maior será a importância de garantir a preponderância da liberdade de expressão, sob pena de reconhecer que este só deverá ser protegido quando se tratar de um conteúdo a que ninguém interessaria proibir ${ }^{62}$.

A insegurança jurídica causada pela falta de uma jurisprudência concreta acerca dos limites da liberdade de expressão e as sanções correspondentes seria, de certa forma, solucionada, dado que o autor da obra teria a convicção de que, a princípio, seu conteúdo estaria protegido e só seria limitado através de posterior comprovação judicial de um abuso ou ilícito, previamente estabelecidos.

\footnotetext{
${ }^{59}$ CHEQUER, Cláudio. Op. Cit. P. 97

${ }^{60}$ BARROSO, Luís Roberto. Op. Cit.

${ }^{61}$ Ibid.

${ }^{62}$ LEITE, Fábio Carvalho. Op. Cit.
} 


\subsection{Principais direitos limitadores ao humor na Constituição}

\section{Brasileira}

\subsubsection{Direito à Honra}

A honra começou a ser discutida como direito amplo e universal, aplicável a todos, após a Segunda Guerra Mundial, quando surgiu a necessidade de garantir ao ser humano proteção a todos os direitos da personalidade, que visavam protegê-lo de qualquer situação que violasse sua dignidade humana. Até então, o direito à honra só recaía sobre uma pequena parte dos indivíduos, aqueles com condição financeira boa, de boa família, e que eram respeitados e admirados, homens da alta sociedade. Os escravos, pobres, e analfabetos, entre outros, estavam fora do que era considerado honrado.

Quando a Declaração Universal da ONU de 1948 dispôs em seu artigo 12 que ninguém será sujeito a ataques à sua honra e sua reputação, o direito à honra passou a ser reconhecido como objeto de proteção de diversos países.

José Afonso da Silva define honra como o "conjunto de qualidades que caracterizam a dignidade da pessoa, o respeito dos concidadãos, o bom nome , a reputação", avançando para dizer que a pessoa tem o direito fundamental de resguardar essas qualidades ${ }^{63}$.

A honra é, portanto, direito fundamental que decorre, de acordo com a doutrina dos principais ordenamentos jurídicos ${ }^{64}$, da dignidade da pessoa humana. Ao proteger a dignidade da pessoa humana, a CF protegeu

\footnotetext{
${ }^{63}$ SILVA, José Afonso da. Op. Cit. P. 209

${ }^{64}$ De acordo com Cláudio Chequer, nos Estados Unidos não dispõe expressamente na sua Constituição qualquer limite à liberdade de expressão mas, ao contrário, determina que "[...] $\mathrm{O}$ Congresso não pode fazer nenhuma lei que limite a liberdade de palavra ou de imprensa.", enquanto a Constituição espanhola expressamente cita, no seu art. 20.4, a honra como um limite às liberdades de informação e de expressão. No entanto, ambas consideram que a honra é direito decorrente da dignidade da pessoa humana. CHEQUER, Cláudio. Op. Cit. P. 62-63
} 
também a honra, não permitindo assim que uma pessoa seja humilhada ou insultada ${ }^{65}$, positivando sua inviolabilidade no inciso $\mathrm{X}$ do art. $5^{\circ}$.

A honra é comumente dividida na doutrina e jurisprudência brasileira como honra subjetiva e honra objetiva. A honra subjetiva diz respeito ao conceito que a pessoa tem de si mesmo, sua auto-estima; enquanto a honra objetiva seria a imagem do indivíduo perante terceiros, sua reputação e o seu nome ${ }^{66}$.

A doutrina brasileira não é a única que faz esta classificação; o autor espanhol Marc Carrillo também aborda o direito à honra sobre duas vertentes. De uma perspectiva subjetiva, o direito à honra seria o sentimento de auto-estima que uma pessoa possuí, relacionada com a consciência da própria dignidade moral; da perspectiva objetiva, a honra seria a reputação, o bom nome, a imagem que tem perante os demais ${ }^{67}$. Essa classificação de Carrillo é reconhecida por outros autores, e também pelo Tribunal Supremo Espanhol ${ }^{68}$.

$\mathrm{O}$ ordenamento jurídico brasileiro dispõe de mecanismos que tutelam o direito à honra, a saber: os crimes tipificados no Código Penal Brasileiro (a calúnia, a difamação e a injúria), o direito de resposta e a responsabilização por ofensas aos direitos da personalidade. Esses mecanismos garantem que os abusos eventualmente praticados pelo livre exercício da liberdade de expressão sejam passíveis de correção, garantindo ao indivíduo cuja honra foi ofendida uma reparação.

\footnotetext{
${ }^{65}$ CHEQUER, Cláudio. Op. Cit. P. 63

${ }^{66}$ GRECO, Rogério. Curso de Direito Penal, Parte Especial: Vol. II. Niterói: Editora Impetus. $8^{\mathrm{a}}$ edição. p. 396

${ }^{67}$ CARILLO, Marc. Los limites a la libertad de prensa en la Constituición española de 1978. PPU Promociones Publicaciones Universitárias. Barcelona. 1987. P. 50. apud REDONDO, Cristina López. La libertad de expresión en situaciones de conflicto. Valencia: tirant lo blanch alternativa. Valencia. 2013. P. 20. "Otra definición interesante del concepto de honor la encontramos em Marc Carrillo, quien lo aborda desde dos vertientes: desde una perspectiva subjetiva es 'el sentimiento de estimación que una persona tiene de si misma em relación con la conciencia de la propia dignidad moral'; mientras que desde un punto de vista objetivo sería 'la reputación, buen nombre o fama de que alguien goza ante los demás'. (...)“

${ }^{68}$ SSTS, 23 de marzo y 26 de junio de 1987, 24 de abril de 1989 y 9 de octubre de 1997. apud REDONDO, Cristina López. Op.Cit. P. 20 "La misma distinción la recogen otros autores como Gonzalo Quintero Olivares así como el propio Tribunal Supremo.“
} 
Segundo Luís Roberto Barroso ${ }^{69}$, a legislação, a doutrina e a

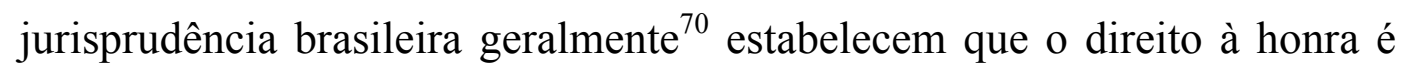
limitado pela veracidade do fato imputado ao indivíduo; hipóteses nas quais sempre prevaleceria o direito à liberdade de expressão. Daí que o direito à honra está diretamente relacionado à liberdade de expressão, uma vez que a honra de uma pessoa só pode ser atingida pelo exercício da liberdade de manifestação de outrem $^{71}$. Isso se agrava quando se trata da utilização do humor nos meios de comunicação, que muitas vezes, tendo o intuito de criticar uma pessoa ou seu ato, acabará por ofender-lhe a honra, criando, conseqüentemente, um conflito onde um dos direitos deverá prevalecer sobre o outro.

\section{Na opinião do Professor Fábio Leite ${ }^{72}$ :}

A liberdade de expressão pode limitar e ser limitada por outros direitos (privacidade, intimidade, direitos da criança e do adolescente, saúde pública), enquanto a honra só pode ser limitada pela liberdade de expressão. Assim, entender que sempre que a honra de uma pessoa é atingida deveria haver condenação ao pagamento de indenização por danos morais seria tornar este um direito absoluto, e, na prática, reduzir a importância da liberdade de expressão a pouco ou quase nada. Afinal, do ponto de vista do ofendido, seria fácil demonstrar que qualquer manifestação contrária à sua honra the causaria um dano.

Desta forma, verifica-se que a honra constitui um limite à liberdade de expressão, da mesma forma que esta pode ser objeto de restrição daquela $^{73}$. Qual dos direitos prevalecerá ficará a cargo do juiz, que analisará os fundamentos e peculiaridades do caso a fim de obter o melhor resultado.

\footnotetext{
69 BARROSO, Luís Roberto. Op. Cit. Disponível em: http://www.migalhas.com.br/arquivo_artigo/art_03-10-01.htm. Acesso em 28 de out de 2014.

${ }^{70} \mathrm{O}$ autor cita uma exceçao: o caso do chamado "segredo da desonra": "fatos que comportam essa exceção envolvem, de forma geral, circunstâncias de caráter puramente privado, sem repercussão sobre o meio social, de tal modo que de forma muito evidente não exista qualquer interesse público na sua divulgação".

${ }^{71}$ LEITE, Fábio Carvalho. Op. Cit.

72 Ibid.

${ }^{73}$ CHEQUER, Cláudio. Op. Cit. P. 93
} 


\subsubsection{Direito à Imagem}

$\mathrm{O}$ direito à imagem é aquele que visa proteger a integridade física da pessoa, seu corpo ou partes dele, e também características pessoais que compõem aquela pessoa, como sua voz, gestos e demais peculiaridades. O direito à imagem tem caráter privado e absoluto, pois é um direito personalíssimo. Quando sua utilização possa ser investida de valor econômico, será também um direito com valor patrimonial. ${ }^{74}$

Antes da promulgação da Constituição de 1988, a proteção ao direito à imagem se dava de forma implícita, no âmbito dos direitos personalíssimos. Com o advento da Constituição, o direito à imagem ganhou status de direito autônomo, tendo o legislador dotado-o de proteção legal adequada, independentemente da configuração de ofensa ou não a outros direitos da personalidade. Além disso, a Constituição estabeleceu a possibilidade de indenização por danos morais e materiais ${ }^{75}$.

O direito à imagem, por sua natureza e, principalmente, nos tempos atuais com fácil acesso às redes sociais, sofre limitações, pois é quase impossível impedir que a imagem da pessoa seja veiculada, uma foto tirada e divulgada, etc. Esses limites podem ser voluntários, decorrentes do consentimento expresso do titular da imagem, ou limitações impostas pelo próprio ordenamento jurídico.

A utilização da imagem de uma pessoa por qualquer meio de comunicação depende, em regra, de autorização do titular. Prevalece o entendimento de que a autorização não é presumida, salvo em casos particulares, e que, uma vez concedida, seria limitada àquele objeto ou fim específico $^{76}$.

\footnotetext{
${ }^{74}$ NETTO, Domingos Franciulli. A proteção ao Direito à Imagem e a Constituição Federal. Disponível http://www.stj.jus.br/publicacaoseriada/índex.php/informativo/article/download/303/287. Acesso em 28 de out de 2014.

${ }^{75}$ Ibid.
} 
Quanto às limitações impostas pelo ordenamento jurídico, podemos citar o artigo 20 do Código Civil, que traz a possibilidade da utilização da imagem da pessoa sem a sua autorização quando necessária à administração da justiça ou à manutenção da ordem pública. A Constituição Federal, em seu art. 93, IX, estabelece um limite ao direito à imagem quando dispõe que os atos judiciais, inclusive os julgamentos, são públicos.

Ressalta-se que a utilização de imagens da pessoa que esteve presente em fatos, acontecimentos ou cerimônias de interesse público, ou desenvolvidas em público, exclui a necessidade de autorização expressa, pois, nestes casos, prepondera o interesse público. Entende Maria Helena Diniz que, nesses casos, a pessoa assume o risco de ser fotografada e ter sua imagem veiculada ${ }^{77}$.

Vale destacar o direito à imagem da pessoa notória, que é limitado pelo interesse público em ralação às informações acerca de sua pessoa. Gozam de proteção, porém, as imagens relativas à sua vida intima e particular, que seriam protegidas pelo direito à intimidade e à vida privada, e sobre o qual a pessoa notória teria direito de exclusividade, podendo impedir sua reprodução quando se configurar dano. Nesse sentido, decidiu o Tribunal de Justiça de São Paulo em 8/06/2002, no julgamento do agravo de instrumento n. 243.037-4/6, pela $9^{\text {a }}$ Câmara de Direito Privado, cujo Rel. Des. foi Sérgio Gomes:

MEDIDA CAUTELAR. Decisão que determinou à recorrida que se abstenha de publicar, divulgar, imprimir ou distribuir quaisquer fotografias atinentes ao casamento dos autores - Admissibilidade - Inviolabilidade da intimidade, da vida privada, da honra e da imagem das pessoas, assegurada a indenizaç ão pelo dano moral e material decorrente de sua violaç ão - Artigo 5o, X, da Constituiç ão da República - Hipótese que mesmo cuidando de conhecido e famoso ator, não é lícito que se invada sua privacidade sob o argumento da liberdade de imprensa - Recurso não provido.

\footnotetext{
${ }^{77}$ DINIZ, Maria Helena. Direito à imagem e sua tutela, in Estudos de direito de autor, direito da personalidade, direito do consumidor e danos morais, coord. Eduardo C. B. Bittar e Silmara Juny Chinelato, Rio de Janeiro, Forense Universitária, 2002, p. 81.
} 
Por fim, salienta-se que o exercício do direito de crítica, de caricatura e de sátira é imune à ilicitude na utilização da imagem alheia, desde que utilizados com esse propósito e não o de denegrir ou ofender a imagem da pessoa retratada.

A jurisprudência consolidou tais entendimentos com diversos julgados, como o proferido pela $6^{\text {a }}$ Câmara de Direito Privado do Tribunal de Justiça de São Paulo, em 31/07/2014, ao julgar a apelação 001796708.2008.8.26.0510, cuja ementa segue:

INDENIZAÇÃO. DANOS MORAIS. Veiculação de matéria jornalística jocosa sobre fato ocorrido. Matéria que informou sobre desentendimento do autor (secretário do turismo) com vereadora. Liberdade de informação. Interesse da coletividade. Prossecução de interesse público na realização e divulgação dos fatos. Excludentes de ilicitude de estatura constitucional, ainda que a matéria tenha conotação cartunesca e jocosa. Conteúdo de sátira e crítica à conduta política do autor. Requerente que, por ser pessoa pública, deve suportar apelo humorístico. Sentença mantida. Recurso improvido.

As ideias acima demonstraram os traços gerais do direito à imagem e seu conflito com a liberdade de imprensa. Ainda assim, o campo para a utilização do humor nos meios de comunicação, quando em conflito com direito à imagem, permanece obscuro. Como veremos a seguir, a jurisprudência ora entende pelo direito à liberdade de expressão, ora entende pelo direito à imagem ou à honra, sem a adoção de critérios razoáveis e concretos.

\subsection{Análise de casos julgados pelos Tribunais Brasileiros}

\subsubsection{Breve estudo de casos}

Neste capítulo, analisaremos alguns casos de uso do humor em conflito com os direitos da personalidade, com foco no direito à honra e à imagem, procurando entender como estes casos são resolvidos na prática. Algumas decisões privilegiam o direito à honra da pessoa em detrimento ao 
direito à liberdade de expressão, conforme veremos brevemente na jurisprudência a seguir:

O primeiro caso trata da ação movida pela cantora Preta Gil em face da Rede TV! em razão de material veiculado no programa Pânico na TV que a autora considerou ofensivo à sua honra e à sua imagem.

A matéria veiculada pelo programa humorístico era uma sátira de um fato ocorrido dias antes, quando a atriz teve uma queda na praia após se desequilibrar por causa de uma onda. No programa, a cantora foi retratada por uma sósia e comparada a uma baleia e um porco.

$\mathrm{O}$ acórdão proferido em sede de Apelação Civil $^{78}$ pela 3a Câmara Cível do Rio de Janeiro manteve a sentença de primeiro grau, entendendo o Des. Rel. que o quadro havia sido ofensivo à imagem da autora, uma vez que "buscou depreciar sua forma física, aquilatando-a de gorda ao fazer uma comparação a um porco e utilizar-se de um trator para retirar uma suposta "sósia" do mar, aduzindo estar a mesma encalhada."

O Des. Luiz Fernando Ribeiro de Carvalho afirmou ainda que:

As expressões pejorativas utilizadas na matéria não estão ligadas unicamente ao exercício da função da Apelante, ultrapassando a razoabilidade do que é tido por engraçado e atingindo a honra da Autora, mesmo sendo ela pessoa pública e que freqüentemente tem suas opiniões estampadas nos meios de comunicação.

Em que pese a autora ser figura pública, os desembargadores entenderam que houve ofensa à honra tendo em vista que o quadro retratado nada tinha a ver com a vida pública da autora e, sim, com suas características pessoais. Além disso, disse o Desembargador Relator que o canal humorístico Pânico na $T V$ não era dotado de conteúdo jornalístico, e "tampouco cunhado de matérias de relevante interesse público".

Caso semelhante foi julgado pela 8a Câmara de Direito Privado do Tribunal de Justiça de São Paulo, na Apelação 9199619-

\footnotetext{
$783^{\text {a }}$ Câmara Cível do Estado do Rio de Janeiro. Apelação Cível 14942/09. Relator: Desembargador Luiz Fernando Ribeiro de Carvalho. Rio de Janeiro, 10 de fev. de 2012
} 
40.2009.8.26.0000 ${ }^{79}$, da Comarca de São Paulo. A ação foi proposta em razão da veiculação da imagem do autor pelo programa Rock Gol da MTV, filmada durante uma partida de futebol realizada no Clube Juventus.

Os fundamentos para a sentença, mantidos integralmente pelo Relator do acórdão, eram de que o autor, visto que não era pessoa pública, deveria ter autorizado a divulgação das imagens, o que não foi concedido.

Em que pese o autor estar freqüentando, no momento da obtenção das imagens, um evento público, sua imagem foi destacada isoladamente e alvo de piadas pelos protagonistas e produtores do programa. Entendeu o Relator que sua imagem havia sido utilizada com o único propósito de exibir o torcedor em situação cômica, uma vez que o autor tinha uma arcada dentária que foi objeto de piadas, o que acabou ridicularizando o demandante.

O terceiro caso diz respeito à determinação da Coordenadora da Fiscalização da Propaganda Eleitoral do E. Tribunal Regional Eleitoral do Rio de Janeiro, Dra. Juíza Daniela Barbosa Assumpção de Souza ${ }^{80}$ ao Google para retirar do ar o vídeo intitulado Você me conhece, do canal humorístico Porta dos Fundos.

O vídeo em questão era uma paródia aos programas eleitorais veiculados na TV, e retratava um candidato fictício a deputado federal Tião do Fuzil, armado, e que ameaçava um refém chamado Marcelo, exigindo votos para que este fosse libertado. Ao final do vídeo o candidato fictício, "seguindo o formato utilizado em diversas propagandas eleitorais verídicas" $" 81$ diz: "Para Governador, Garotinho".

A juíza, entendendo que o vídeo seria uma propaganda negativa contra o candidato ao governo do Estado, Sr. Anthony Garotinho, ao relacioná-lo à prática de crimes e a organizações criminosas, afirmou que:

\footnotetext{
79 8a Câmara de Direito Privado do Tribunal de Justiça de São Paulo. Apelação 919961940.2009.8.26.0000. Relator: Pedro de Alcâ ntara da Silva Leme Filho. São Paulo, 1 de outubro de 2014.

${ }^{80}$ Reclamação 18776 ajuizada perante o STF pela Clínica de Direitos Humanos da UERJ contra a decisão de Protocolo no 158.287/2014. Disponível em: http://uerjdireitos.com.br/clinica-uerjdireitos-atua-em-caso-de-censura-ao-canal-porta-dos-fundos/. Acesso em 29 de out. 2014.

${ }^{81}$ Ibid.
} 
Não se pretende coibir o direito à liberdade de pensamento ou à livre expressão artística, mas estes direitos não podem se sobrepor aos direitos individuais da pessoa humana (...)

Por fim, a juíza considerou que houve um abuso do direito à liberdade de expressão, entendendo que o único intuito do uso desmedido do mesmo havia sido o de prejudicar o candidato Anthony Garotinho e fazer propaganda eleitoral negativa em relação a este.

A Clínica de Direitos Humanos da UERJ ajuizou uma Reclamação perante o STF, argüindo que a decisão do TRE-RJ contrariava entendimento firmado pelo Tribunal, em sede de julgamento da ADI número 4.451 (que será analisada em seguida). O Min. Dias Toffoli negou seguimento ao mesmo por entender que a via processual escolhida não era adequada, ao considerar que a decisão atacada não desafiou frontalmente o entendimento do STF. Afirmou o Ministro que:

No caso dos autos, não verifico a identidade entre o debate travado na presente reclamação e o entendimento vinculante apto a instaurar o exercício da jurisdição, em sede reclamatória, pelo Supremo Tribunal Federal ${ }^{82}$

Além disso o Ministro entendeu que a decisão questionada não configuraria censura prévia, e estava fundamentada em indícios de violação ao direito à imagem do candidato, o que é considerado inconstitucional pelo STF.

Apesar das decisões acima terem privilegiado o direito à honra e à imagem em detrimento do direito à liberdade de expressão, encontramos diversas decisões em que o oposto acontece, e é dada preferência ao direito à liberdade de expressão. Algumas delas veremos a seguir.

A decisão proferida na $\mathrm{ADI}$ de número $4.451^{83}$, citada no caso acima, foi muito importante no âmbito da liberdade de expressão em época

\footnotetext{
${ }^{82}$ Notícias STF. Disponível em: http://www.stf.jus.br/portal/cms/verNoticiaDetalhe.asp?idConteudo=276832. Acesso em 29 de out. 2014.

${ }^{83}$ STF, ADI 4451 MC, Rel. Min. AYRES BRITTO, julgado em 26/08/2010, DJ 01/09/2010.
} 
de eleição. A ADI foi ajuizada pela ASSOCIACÃO BRASILEIRA DE RÁDIO E TELEVISÃO - ABERT visando à declaração de inconstitucionalidade dos incisos II e III do artigo 45 da Lei 9.504/97, quais sejam:

Art. 45. A partir de $1^{\circ}$ de julho do ano da eleição, é vedado às emissoras de rádio e televisão, em sua programação normal e noticiário:

I - transmitir, ainda que sob a forma de entrevista jornalística, imagens de realização de pesquisa ou qualquer outro tipo de consulta popular de natureza eleitoral em que seja possível identificar o entrevistado ou em que haja manipulação de dados;

(...)

III - veicular propaganda política ou difundir opinião favorável ou contrária a candidato, partido, coligação, a seus órgãos ou representantes;

Os julgadores, por maioria, decidiram por suspender as normas do inciso II e da segunda parte do inciso III, ambos do artigo 45, bem como, por arrastamento, dos $\S \S 40$ e 5o do mesmo artigo da Lei federal no 9.504, de 30/9/97.

No caso do inciso II, o STF entendeu que este não garantia a imparcialidade das emissoras de rádio e televisão, e coibia um estilo peculiar de técnica de expressão dos programas humorísticos.

Quanto ao inciso III, o tribunal suspendeu a eficácia da expressão "ou difundir opinião favorável ou contrária a candidato, partido, coligação, a seus órgãos ou representantes”, entendendo que:

Apenas se estará diante de uma conduta vedada quando a crítica ou matéria jornalísticas venham a descambar para a propaganda política, passando nitidamente a favorecer uma das partes na disputa eleitoral. Hipótese a ser avaliada em cada caso concreto.

Alguns trechos da decisão chamam a atenção pelo respeito à liberdade de expressão e de imprensa, como quando afirmam que não é papel do Estado definir previamente o que pode ou o que não pode ser dito por indivíduos ou jornalistas. Entenderam os Ministros que "não há liberdade de imprensa pela metade ou sob as tenazes da censura prévia(...)" ao passo que seu conteúdo é protegido constitucionalmente, pelo art. $22^{\circ}$ da 
$\mathrm{CRFB} / 88^{84}$. Asseguraram ainda que a liberdade de imprensa não pode sofrer restrições em período eleitoral; há de ser "plena em todo o tempo, lugar e circunstâncias”.

Quanto à utilização do humor, concluiu o Tribunal que os programas humorísticos gozam da plenitude da liberdade de expressão assegurada pela Constituição:

(...) o exercício concreto dessa liberdade em plenitude assegura ao jornalista o direito de expender críticas a qualquer pessoa, ainda que em tom áspero, contundente, sarcástico, irônico ou irreverente, especialmente contra as autoridades e aparelhos de Estado (grifo no original)

A crítica jornalística em geral, de acordo com os julgadores, não é suscetível à censura, pois é essência da imprensa operar como formadora de opinião pública. Nesse sentido, o uso do "humor jornalístico" une pensamento crítico, informação e criação artística.

A ação que deu origem à Apelação número 001796708.2008.8.26.0510 ${ }^{85}$, da Comarca de Rio Claro, em São Paulo, foi proposta por conhecido político daquela cidade, à época secretário de turismo da cidade, visando à reparação de dano moral que lhe teria sido causado pela veiculação de matéria jornalística supostamente ofensiva à sua dignidade.

O acórdão manteve a decisão de primeira instância, sustentando que a matéria jornalística estava coberta por "excludente de antijuridicidade de

\footnotetext{
${ }^{84}$ Nesse sentido, dispõe o item 2 da Ementa da ADI n. 4.451: "Não cabe ao Estado, por qualquer dos seus órgãos, definir previamente o que pode ou o que não pode ser dito por indivíduos e jornalistas. Dever de omissão que inclui a própria atividade legislativa, pois é vedado à lei dispor sobre o núcleo duro das atividades jornalísticas, assim entendidas as coordenadas de tempo e de conteúdo da manifestaç ão do pensamento, da informaç ão e da criaç ão lato sensu. Vale dizer: não há liberdade de imprensa pela metade ou sob as tenazes da censura prévia, pouco importando o Poder estatal de que ela provenha. Isso porque a liberdade de imprensa não é uma bolha normativa ou uma fórmula prescritiva oca. Tem conteúdo, e esse conteúdo é formado pelo rol de liberdades que se lê a partir da cabeç a do art. 220 da Constituiç ão Federal: liberdade de "manifestação do pensamento", liberdade de "criação", liberdade de "expressão", liberdade de "informação". Liberdades constitutivas de verdadeiros bens de personalidade, porquanto correspondentes aos seguintes direitos que o art. 5o da nossa Constituiç ão intitula de "Fundamentais": a) "livre manifestação do pensamento" (inciso IV); b) "livre [...] expressão da atividade intelectual, artística, cientifica e de comunicação" (inciso IX); c) "acesso a informação" (inciso XIV)." (grifo no original)

${ }^{85} 6$ a Câmara de Direito Privado do Tribunal de Justiça de São Paulo. Apelação número 001796708.2008.8.26.0510. Relator: Desembargadora Ana Lucia Romanhole Martucci. São Paulo, 31 de julho de 2014.
} 
jaez constitucional, da liberdade de informação e de expressão." No caso, os julgadores entenderam que o assunto era de interesse público da comunidade local, tendo em vista que o conteúdo da matéria dizia respeito a suposto desrespeito entre o secretário de turismo da cidade (autor), e uma vereadora, e foi noticiado que o autor não permitiu que a vereadora falasse em evento público. Além disso, atentaram para o fato de ser o autor figura pública da cidade e, portanto, deve suportar o ônus que tal cargo lhe impõe.

Outra ação cujo tema é semelhante foi julgado pela 3a Câmara de Direito Privado do Tribunal de Justiça de São Paulo na apelação número 0000465-52.2012.8.26.0272 ${ }^{86}$, da Comarca de Itapira.

A ação por danos morais foi ajuizada por Alexandre Salvarani em face da Gazeta Itapirense em razão de uma charge publicada pela Gazeta, que o mostrava como faxineiro, e sugerindo que ele seria apenas um criado de seus colegas de trabalho no departamento em que ocupava na Prefeitura Municipal de Itapira.

A Relatora começou seu voto afirmando que, para que haja responsabilidade civil por ato ilícito, exige-se, quando se almeja a reparação, que a vítima prove o dano e a conduta culposa do agente, ligados pelo nexo de causalidade, entendendo que tal não ocorria no caso em questão. Entendeu ainda que a charge não foi uma forma de agressão à imagem do autor, pois é instrumento da democracia a utilização do humor para criticar os ocupantes de cargos públicos.

Por fim, alega que, por ser figura pública, deveria estar preparado para suportar ser alvo de criticas humorísticas:

Devia, portanto, estar preparado para suportar notas, charges e caricaturas, reveladores do animus jocandi, tais como as que não raras vezes são suportadas pelos membros dos Poderes Executivo, Legislativo e Judiciário, nos mais diversos meios de comunicação, sem que isso implique em afronta à sua honra.

\footnotetext{
${ }^{86}$ 3a Camara de Direito Privado do Tribunal de Justiç a de São Paulo. Apelação número 0000465-52.2012.8.26.0272, da Comarca de Itapira. Relator: Desembargadora Viviani Nicolau. São Paulo, 3 de julho de 2014 .
} 
Podemos perceber, através dos casos apresentados, uma certa tendência dos Tribunais a garantir a liberdade de expressão e de imprensa quando a pessoa retratada é figura pública, e quando as criticas dizem respeito à vida pública dos mesmos e suas funções. Todavia, quando se está diante de crítica humorística dirigida à própria pessoa ou alguma característica física sua, entende o judiciário pela ofensa à honra ou à imagem da pessoa retratada.

A princípio, pode parecer que há uma harmonização no entendimento do judiciário acerca do conflito observado, no entendo, vale mencionar que esta harmonização é apenas aparente, conforme explicitado pela oposição do entendimento firmado pelo STF no julgamento da ADI No. 4.451 e a sentença proferida pela juíza do TRE.

\subsubsection{A Ponderação como forma de resolução dos conflitos}

Diante da existência, não rara, de conflitos entre direitos fundamentais, surge a necessidade da adoção de uma forma de resolução adequada. Essa técnica, comumente utilizada pelos julgadores, é a ponderação.

A ponderação é aplicável a casos difíceis ${ }^{87}$, principalmente quando em uma situação concreta há um conflito entre duas ou mais normas de mesma hierarquia e é preciso decidir qual das duas prevalecerá.

O Min. Luís Roberto Barroso simplifica o processo da ponderação em três etapas ${ }^{88}$, quais sejam:

$\mathrm{Na}$ primeira, o intérprete deve detectar quais as normas relevantes para a solução do caso concreto, identificando os eventuais conflitos entre elas.

\footnotetext{
${ }^{87}$ Do inglês hard cases, a expressão identifica situações para as quais não há uma formulação simples e objetiva a ser colhida no ordenamento, sendo necessária a atuação subjetiva do intérprete e a realização de escolhas, com eventual emprego de discricionariedade. BARROSO, Luís Roberto. Op. Cit.

${ }^{88}$ Ibid.
} 
$\mathrm{Na}$ segunda etapa, o intérprete deve examinar os fatos, e as circunstâncias concretas do caso, e sua interação com as normas identificadas na etapa passada, e a partir daí a norma terá sentido prático. Sobre isso, dispõe o autor que:

(...) os fatos e as conseqüências práticas da incidência da norma têm assumido importância especial na moderna interpretação constitucional. Embora os princípios e regras tenham, em tese, uma existência autônoma, no mundo abstrato dos enunciados normativos, é no momento em que entram em contato com as situações concretas que seu conteúdo se preencherá de real sentido. Assim, o exame dos fatos e os reflexos sobre eles das normas identificadas na primeira fase poderão apontar com maior clareza o papel de cada uma delas e a extensão de sua influência.

Na terceira etapa, que consiste na fase decisória da técnica, serão examinadas, juntas, as normas e a repercussão dos fatos concretos, para que se possa atribuir a respectiva importância a cada um dos elementos analisados e, assim, determinar qual norma deverá prevalecer no caso.

Lembra o autor que os princípios, por sua natureza e, dentro de certos limites, podem ser aplicados com maior ou menor intensidade, à vista das circunstâncias jurídicas e fáticas do caso sob análise. Entendendo a doutrina e jurisprudência que, quando o conflito versar sobre direitos da personalidade, é possível ainda identificar um elemento decisivo à determinação do grau de intensidade de sua proteção: o fato de a pessoa ser uma figura pública, em razão de seu cargo ou atividade, ou até mesmo por alguma circunstância eventual.

Daí que, em seguida, determina o autor que seja decidido o grau de intensidade em que a norma, e a solução por ela indicada, deve ser prevalecer sobre a outra e o grau de intensidade de sua aplicação. O fio condutor deste processo é chamado de princípio instrumental da proporcionalidade ou razoabilidade ${ }^{89}$.

Definida a técnica da ponderação e, com base na exposição anterior, podemos dizer que o direito à liberdade de expressão e de imprensa é um

\footnotetext{
${ }^{89}$ BARROSO, Luís Roberto. Op. Cit.
} 
direito de interesse público, considerando que este é um de seus fundamentos, e que o direito à imagem e à honra seriam direitos de interesse privado, uma vez que dizem respeito à própria pessoa, seu titular.

Neste caso, em que ambos os direitos possuem a mesma hierarquia e importância o juiz deve agir com cautela para que não sacrifique um direito mais do que o necessário, ao dar preferência ao outro. É possível a harmonização dos direitos e a aplicação de um desfecho que garanta, pelo menos em parte, todos os direitos fundamentais em conflito.

Nesse contexto, o direito de resposta surge como uma solução idea $1^{90}$, apta a garantir ambos os direitos, em casos de conflito entre liberdade de expressão e direito à honra. Sobre isso, dispõe o professor Fábio Leite:

O direito de resposta é a forma mais justa de o Estado assegurar o direito à honra, sem se comprometer com o conteúdo que gerou o dano ou, mais especificamente, com a reputação do ofendido diante de si próprio ou do meio social. $^{91}$

O direito de resposta, seria, assim, um meio eficaz para a resolução da lide, pois permitiria a divulgação do conteúdo objeto de conflito e, ao mesmo tempo, a defesa dos fatos divulgados pelo retratado, dando-lhe a chance de contar a sua versão dos fatos.

\subsubsection{Critérios de avaliação adotados pelos tribunais}

Luís Roberto Barros indica alguns elementos que devem ser verificados pelo juiz na hora da ponderação entre liberdade de expressão e informação, de um lado, e os direitos à honra e à imagem de outro, os quais analisaremos a seguir ${ }^{92}$ :

\footnotetext{
${ }^{90}$ LEITE, Fábio Carvalho. Op. Cit.

91 Ibid.

${ }^{92}$ BARROSO, Luís Roberto. Op. Cit.
} 
1) Se o fato é verdadeiro: "a informação que goza de proteção constitucional é a informação verdadeira" afirma Barroso, incluindo que a divulgação deliberada de uma notícia falsa gera a responsabilização do emissor, uma vez que os veículos de comunicação têm o dever de apurar, com boa-fé, a veracidade dos fatos veiculados.

2) Se o meio empregado para obter a informação foi lícito: os fatos divulgados devem ter sido obtidos por meios admitidos em direito. Aqui se aplica o conceito da teoria do fruto da árvore envenenada ${ }^{93}$, utilizado no Direito Penal. Da mesma forma, a Constituição estabelece que é ilícita a divulgação de notícias às quais se teve acesso por meios ilegais, por exemplo, através de uma excuta telefone ilegal, violação de segredo de justiça, entre outros.

3) Se a pessoa é pública ou anônima: conforme visto no capítulo anterior, a jurisprudência entende que as pessoas que ocupam cargos públicos têm o seu direito à imagem mitigado pelo interesse público que recaí sobre sua vida.

4) Local de obtenção do fato divulgado: os fatos ocorridos em local público, ou eventos públicos, a princípio, podem ser noticiados sem o consentimento da pessoa retratada, conforme ilustrado nos acórdãos estudados anteriormente.

5) A natureza do fato: acontecimentos notórios, que independem dos envolvidos, são passíveis de divulgação ainda que possam violar à imagem ou intimidade dos envolvidos, como é o caso de acontecimentos da

\footnotetext{
${ }^{93}$ Essa Teoria determina que as provas ilícitas, ou obtidas com o emprego de meios ilícitos, não podem ser produzidas pelas partes no processo, devendo, na hipótese de sua produção, serem excluídas do feito. A Constituição Federal de 1988 positivou essa teoria no inciso LVI do art. $5^{\circ}$ ao estabelecer que: "São inadmissíveis, no processo, as provas obtidas por meios ilícitos.“.
} 
natureza, acidentes, e fatos de repercussão geral, como por exemplo, passeatas.

6) Se há interesse público na sua divulgação: quando houver interesse público na divulgação de alguma material jornalística, o direito à liberdade de informação, enquanto formador de opinião pública e fonte de informação à população, será resguardado.

7) Se há interesse público na divulgação de fatos relacionados ao poder público: a publicidade, prevista no art. $5^{\circ}$, inciso XXXIII da CF, deve ser aplicada como regra geral. Essa publicidade se aplica a toda administração pública, direta ou indireta, pois é o mecanismo que garante ao povo o controle da atuação dos agentes.

8) Preferência por sanções a posteriori: o uso abusivo da liberdade de expressão e de informação pode ser reparado por mecanismos diversos, que de certa forma impedem que o conteúdo da divulgação sofra uma censura prévia. Barroso entende que somente em hipóteses extremas se deverá utilizar a última opção, onde a reparação posterior não seria proporcional ao dano já causado ${ }^{94}$.

De fato, a partir da análise dos casos no item 3.2.1, o Min. Luís Roberto Barroso reúne critérios que já vêem sendo utilizados com freqüência pelos tribunais brasileiros. A questão é que, tratando-se de direitos fundamentais extremamente amplos e subjetivos, é quase impossível prever como será a solução de um conflito, $\mathrm{O}$ que uns

\footnotetext{
${ }^{94} \mathrm{O}$ autor cita como exemplo os seguintes casos: "Nas questões envolvendo honra e imagem, por exemplo, como regra geral será possível obter reparação satisfatória após a divulgação, pelo desmentido - por retificação, retratação ou direito de resposta - e por eventual reparação do dano, quando seja o caso. Já nos casos de violação da privacidade (intimidade ou vida privada), a simples divulgação poderá causar o mal de um modo irreparável. Veja-se a diferença. No caso de violação à honra: se a imputação de um crime a uma pessoa se revelar falsa, o desmentido cabal minimizará a sua conseqüência. Mas no caso da intimidade, se se divulgar que o casal se separou por disfunção sexual de um dos cônjuges - hipótese que em princípio envolve fato que não poderia ser tornado público - não há reparação capaz de desfazer efetivamente o mal causado."
} 
consideram ofensa à sua imagem, para outros pode ser apenas uma brincadeira ou, inclusive, até motivo de felicidade, pois, conforme entendeu o Tribunal Supremo espanhol, o conceito jurídico de honra depende da delimitação que cada pessoa faz acerca de seus próprios atos e se eles integram ou não sua vida íntima e pessoal ${ }^{95}$.

Quanto ao ultimo critério proposto por Barroso, Fábio Leite dispõe o seguinte:

O primeiro ponto a ser considerado na análise de qualquer caso envolvendo liberdade de expressão é que a diferença entre restrição prévia (judicial ou mesmo governamental) e sanção judicial posterior não apenas é pequena - certamente menor do que se imagina - como, do ponto de visa de quem se expressa, a segunda pode ser pior do que a primeira, ou tão ruim quanto. Se a assertiva estiver correta, devemos indagar por que absolutamente todas as razões que justificam a vedação à censura prévia simplesmente desaparecem quando se trata de impor sanção posterior ${ }^{96}$.

Seria o caso, por exemplo, de o autor ser condenado ao pagamento de indenização. Nesse caso, poderíamos indagar se o autor não iria preferir saber, previamente, que sua obra não estaria sobre a proteção do direito à liberdade de expressão. ${ }^{97}$

Em que pese à utilidade dos critérios adotados pelos tribunais brasileiros e elencadas pelo Min, Barroso, Fábio Leite defende que há uma

\footnotetext{
95 “Artículos 2.1. 'La Protección Civil Del Honor, de la Intimidad y de la Propia Imagen quedará delimitada por lãs leyes y por los usos sociales atendiendo AL ámbito que, por sus propios actos, mantenga cada persona reservado para sí misma o sua familia'“. apud REDEONDO, Cristina López. Op. Cit. P. 21: "Esta proteción también dependerá de la delimitación que cada persona haga a traves de sus propios actos.“

${ }^{96}$ LEITE, Fábio. Op. Cit.

${ }^{97}$ Sobre o assunto, Fábio Leite destaca o seguinte caso: "Há alguns anos, um pequeno jornal da cidade de Santa Cruz do Rio Pardo, interior de São Paulo, foi condenado a pagar o valor de R\$ 593 mil de indenização a um juiz por conta de uma reportagem em que se afirmava que a Prefeitura custeava os gastos do magistrado com o aluguel de sua residência e sua conta telefônica. $\mathrm{O}$ valor da indenização correspondia a 2,5 anos de faturamento bruto da empresa, o que sugere que a consequência desta condenação seria o fechamento definitivo do jornal. Deixando de lado o mérito deste caso, não seria razoável supor que, se o dono do jornal soubesse que a publicação da reportagem geraria uma condenação no valor de 593 mil reais, ele preferiria não ter divulgado a matéria e assim mantido o seu jornal em funcionamento? Em outras palavras, será que o próprio dono do jornal não preferiria uma proibição prévia (a uma reportagem) do que uma condenação posterior (que implicaria, na prática, o fim do jornal)? Se correta a suposição, então haveria uma vantagem em submeter-se a um procedimento semelhante ao da censura do regime autoritário em lugar de desfrutar de uma liberdade de expressão assegurada pela Constituição democrática.".
} 
necessidade de alteração radical na forma como os conflitos envolvendo a liberdade de expressão são resolvidos pelo Poder Judiciário brasileiro.

Como uma nova forma de solucionar os conflitos, o autor apresenta quatro diretrizes, a saber: (1) compreender que a censura judicial é ou pode ser semelhante à censura governamental em seus efeitos; (2) reconhecer uma posição preferencial da Liberdade de expressão em conflito com o direito à honra; (3) decidir estes conflitos com eficácia inter partes, mas com uma perspectiva erga omnes; (4) considerar o direito de resposta como sanção preferencial ${ }^{98}$.

Nessa primeira diretriz, o autor defende a questão mencionada anteriormente; que a diferença entre restrição prévia (judicial ou governamental) e sanção judicial posterior não apenas é pequena ou tão ruim quanto. Sustenta Fábio Leite que o bônus da liberdade de expressão e manifestação, bem como a livre circulação de ideias é compartilhado com o público, porém o ônus da sanção posterior é suportado exclusivamente por quem se expressa. Continua afirmando que:

Ou seja, na medida em que não se admite restrição prévia, não houve obstáculo ao livre mercado de ideias e as críticas (duras e pesadas) contribuíram para o debate público. Do ponto de vista da coletividade, a liberdade de expressão, na sua concepção formalista, garantiu a livre circulação de ideias, de que tanto depende a democracia. Do ponto de vista do autor das críticas, a difusão de seu pensamento custou-lhe uma quantia considerável, que poderá fazer com que nunca mais manifeste suas opiniões - justamente aquelas que foram importantes para o debate público.

Portanto, na visão do autor, a proibição estrita à censura prévia abriria espaço a uma censura invisível, a autocensura., devido ao o receio do autor de vir a ser condenado por algo que escreveu ou manifestou.

A segunda diretriz, mencionada anteriormente, é baseada em ordenamentos jurídicos como o do Estados Unidos. O autor entende que uma posição preferencial do direito à liberdade de expressão seria justificado pela ideia de casos difíceis, onde não há um meio termo, e uma

\footnotetext{
${ }^{98}$ LEITE, Fábio. Op. Cit.
} 
das partes não terá, obrigatoriamente, seu interesse atendido. No caso de conflitos entre a liberdade de expressão e o direito à honra, o autor sustenta a preferência daquela devido a dois argumentos: o primeiro é que a "liberdade de expressão, nas situações em que se revela importante, necessariamente ou provavelmente afeta a honra de alguém”, pois, conforme mencionado anteriormente, quanto mais forte for o comentário, a opinião ou a crítica, maior será a importância da garantia da liberdade de expressão; o segundo, que se relaciona com o primeiro, é que a honra de uma pessoa só pode ser atingida pelo exercício do direito à liberdade de expressão.

A terceira diretriz é defendida pelo simples fato de não haver harmonização no entendimento acerca dos conflitos objeto deste estudo nos tribunais brasileiros, conforme uma pesquisa coordenada pelo próprio Fábio Leite $^{99}$. Defende o autor que os juízes adotem uma perspectiva erga omnes ao decidir casos inter partes, o que uniformizaria a interpretação de uma perspectiva universalizante, aplicável a todos, e não somente aquele caso específico, garantindo, assim, maior segurança jurídica acerca destes conflitos.

A quarta, e última, diretriz defende o direito de resposta como sanção preferencial. Questiona o autor a raridade dos casos em que a condenação por ofensa à honra foi, ou incluiu, o direito de resposta, visto que, na pesquisa que coordenou, nos 45 casos em que o STJ decidiu em favor dos direitos da personalidade, dentre 57, em nenhum houve condenação para assegurar o direito de resposta. Isso poderia ser explicado pelo fato de que os próprios autores sequer requereram o direito como condenação. ${ }^{100}$

\footnotetext{
${ }^{99}$ LEITE, Fábio. "Uma pesquisa realizada junto ao Superior Tribunal de Justiça, levantando decisões (em Recursos Especiais e apenas na esfera cível) sobre os conflitos entre liberdade de expressão e direitos da personalidade em geral, no período de 2002-2010, revelou que, num universo de 57 acórdãos, somente em $12 \mathrm{o}$ tribunal entendeu que deveria prevalecer o direito à liberdade de expressão". Relatório da pesquisa disponível em: http://www.pucrio.br/pibic/relatorio_resumo2013/relatorios_pdf/ccs/DIR/DIR-

Luisa\%20Soares\%20Ferreira\%20Lobo.pdf. Acesso em: 02 de out. de 2014.

100 "Curiosamente, são raríssimos os casos em que a condenação por ofensa à honra sequer "inclui" o direito de resposta. Considerando-se, por exemplo, os 45 casos em que o STJ decidiu em favor dos direitos da personalidade (no universo de 57 acórdãos citados acima), em absolutamente nenhum houve condenação para assegurar o direito de resposta. $\mathrm{O}$ resultado poderia ser explicado pelo fato de o direito de resposta não ser adequado em determinadas situações ou por não terem os próprios autores requerido este direito. No universo em questão, no entanto, o direito de resposta seria cabível em 33 dos 57 casos, mas só houve pedido em 7 deles (e sempre de forma subsidiária)." LETE, Fábio. Op. Cit.
} 
Na visão do autor, estaríamos diante de um círculo vicioso, onde os juízes não concedem porque os autores não requerem, e os autores não requerem porque podem optar pelo pedido de indenização. Sustenta o autor que a lógica deveria ser outra: em regra, o dano à honra decorrente da liberdade de expressão deveria ser suportado. Excepcionalmente, aquele que se expressa deveria reparar o dano e, alem disso, a condenação deveria, em regra, se limitar ao direito de resposta.

O direito de resposta não só é a forma mais justa de o Estado assegurar o direito à honra, sem se comprometer com o conteúdo que gerou o dano, mas ainda acrescenta ao debate público, dando ao público a possibilidade de conhecer os dois lados da controvérsia. 


\title{
CONCLUSÃO
}

Após o conteúdo analisado, observamos ser recorrente o confronto entre o direito à liberdade de expressão, compreendido como o direito de livre manifestação do pensamento e o direito de informar, e os direitos à honra e a imagem. Esse confronto é evidenciado quando no âmbito do jornalismo humorístico, mas não é exclusivo a este.

$\mathrm{O}$ uso do humor no jornalismo humorístico permite uma combinação do dever primordial da função jornalística de informar com precisão à coletividade, o e o uso de uma linguagem mais rebuscada e acessível, objetivando alcançar o telespectador com maior facilidade. $\mathrm{O}$ humor também pode ser importante instrumento de crítica, a exemplo das charges e das caricaturas retratando situações ou pessoas, muitas vezes políticos.

No entanto, a partir dos casos práticos que analisamos, percebemos que o direito à liberdade de expressão é fortemente defendido na teoria mas, na prática, é facilmente afastado quando entra em conflito com o direito à honra ou o direito à imagem.

Sobre isso, dispõe Fábio Leite:

\begin{abstract}
Nem mesmo a mais civilista das abordagens ignora que a liberdade de expressão é essencial à democracia. Mas defender a liberdade de expressão é aceitar as suas consequências, e é neste ponto que o pensamento jurídico brasileiro parece vacilar. De nada adianta enaltecer o valor da liberdade de expressão (como em geral fazem os magistrados de forma preambular em suas decisões) se qualquer dano à honra, que já deveria ser esperado, é logo reconhecido como um limite àquele direito. A facilidade com a qual um dano sofrido por conta de ofensas é considerado um limite à liberdade de expressão coloca em dúvida a importância da liberdade de expressão e, por fim, a concepção que se tem de democracia.
\end{abstract}

Essa falta de uniformização pôde ser observada nas decisões proferidas pelo STF, na ADI 4.451 e pela juíza Juíza Daniela Barbosa Assumpção de Souza do TRE-RJ . Enquanto o STF decidiu que o exercício do direito à liberdade de expressão deveria ser livre, inclusive em período eleitoral, a juíza entendeu que, por ser tratar de vídeo veiculado em época 
de período eleitoral, esse seria prejudicial à campanha do então candidato a Governador do Estado, Anthony Garotinho. Cumpre indagar se, caso o vídeo fosse veiculado em qualquer outra época, teria sido permitido, ou se o entendimento da juíza seria o mesmo.

Além disso, há certa insegurança jurídica em relação aos casos envolvendo tais conflitos, ao passo que não há uniformização no entendimento adotado pelos tribunais, cada qual decidindo de acordo com o caso concreto, sem adotar uma perspectiva que possa ser aplicada à maior parte dos casos.

Por isso, afim de sanar essas deficiências do judiciário brasileiro, a posição preferencial da liberdade de expressão deve ser mais profundamente discutida pela doutrina e jurisprudência brasileira.

Não se trata de afirmar que um direito é superior ao outro mas, sim, de garantir ao direito à liberdade de expressão uma preferência a priori, que poderia ser afastada caso fosse comprovado um eventual abuso cometido.

Por fim, deve o direito de resposta ganhar maior efetividade como forma de condenação no judiciário, principalmente quando o conflito envolver o direito à honra. $\mathrm{O}$ direito de resposta deve ser visto como "um trunfo previsto na Constituição"101, pois permite que seja assegurado o direito à honra, sem se comprometer com o conteúdo que gerou a ofensa. Ademais, agregaria ao debate público, dando a este a possibilidade de conhecer os dois lados do conflito e de formular seu próprio juízo acerca do mesmo.

\footnotetext{
${ }^{101}$ LEITE, Fábio. Op. Cit.
} 


\section{BIBLIOGRAFIA}

AFONSO DA SILVA, José. In. Curso de Direito Constitucional Positivo, Malheiros Editores, 34a edição, 2011.

ARAÚJO, Amanda e BRAGA, Vinícius. Quando o humor vira coisa séria. Disponível em: http://jornalismo.fic.ufg.br/pages/30997-quando-o-humorvira-coisa-seria. Acesso em: 20 de set. de 2014.

ÁVILA, Fernanda Góes de Oliveira. Análise do discurso humorístico: as condições de produção das piadas de Joãozinho. Universidade Estadual de Campinas - Instituto de Estudos da Linguagem. Disponível em: www.bibliotecadigital.unicamp.br/document/?down=40991. Acesso em 20 de set. De 2014.

BARROSO, Luis Roberto. Colisão entre liberdade de expressão e direitos da personalidade. Critérios de ponderação. Interpretação constitucionalmente adequada do Código Civil e da Lei de Imprensa. Revista Trimestral de Direito Civil, Rio de Janeiro, v. 16, p. 59-102, 2004.

BERGSON, Henri. O Riso. Disponível em http://minhateca.com.br/livros_gratis_BR/BERGSON*2c+Henri.+O+Riso, 68366.pdf. Acesso em 20 de set. de 2014.

CARVALHO, Luis Gustavo Grandinetti Castanho de. Direito de Informação e liberdade de expressão. Rio de Janeiro: Renovar, 1999.

CAVALIERI FILHO, Sérgio. Programa de Responsabilidade Civil. 10 Ed. São Paulo: Atlas, 2012. 
CHEQUER, Cláudio. A Liberdade de Expressão como Direito Fundamental Preferencial Prima Facie (análise crítica e proposta de revisão ao padrão jurisprudencial brasileiro). Rio de Janeiro: Lumen Júris, 2011.

Constituição da República.

COSTA, Cristina. Censura em cena: teatro e censura no Brasil. São Paulo: EDUSP: FAPESP: Imprensa oficial do Estado de São Paulo, 2006.

CURY, JÚNIOR, David. A proteção jurídica da imagem da criança e do adolescente. Disponível em: http://www.dominiopublico.gov.br/download/teste/arqs/cp011640.pdf. Acesso em 29 de outubro de 2014.

DINIZ, Maria Helena. Direito à imagem e sua tutela, in Estudos de direito de autor, direito da personalidade, direito do consumidor e danos morais, coord. Eduardo C. B. Bittar e Silmara Juny Chinelato, Rio de Janeiro, Forense Universitária, 2002.

GRECO, Rogério. Curso de Direito Penal, Parte Especial: Vol. II. Niterói: Editora Impetus. $8^{\mathrm{a}}$ edição.

GUIMARÃES, Silvia Bragatto. Estratégias persuasivas da linguagem humorística: análise de cartuns educativos. Disponível em http://www.filologia.org.br/xiicnlf/06/08.pdf. Acesso em 20 de set. de 2014. 
JORGE, Carlos Leronardo Weber. Onde está a graça? - O humor segundo Bérgson em contos de Mark Twain. Disponível em, http://www.letras.ufpr.br/documentos/graduacao/monografias/ss2009/Onde-graca.pdf. Acesso em: 02 de out. de 2014.

JUNIOR, Vidal Serrano Nunes. A Proteção Constitucional da Informação e o Direito à Crítica Jornalística. Coordenação; Hélio Bicudo. Sao Paulo: FTD, 1997

Lei No. 9.610.

Lei No. 9.504/97

LEITE, Fábio Carvalho. Liberdade de Expressão e Direito à Honra: novas diretrizes para um velho problema. In CLEVE, Clemerson Merlin, FREIRE,Alexandre (Org.) Direitos Fundamentais e Jurisdição Constitucional. São Paulo: Ed. Revista dos Tribunais, 2014 (no prelo).

LEMOS, Ronaldo. Entre aspas, humor. Folha de S. Paulo. Disponível em: http://www.observatoriodaimprensa.com.br/news/view/jornalismo_mistura do_com_humor. Acesso em 15 de set. de 2014.

LIMA, Isabelle Moreira. Grupo de humor Porta dos Fundos enfrenta ira de religiosos por especial de Natal. Disponível em: http://www1.folha.uol.com.br/ilustrada/2014/01/1395628-grupo-de-humorporta-dos-fundos-enfrenta-ira-de-religiosos-por-especial-de-natal.shtml. Acesso em: 25 de set. de 2014. 
LOBO, Luisa Soares Ferreira. Liberdade de Expressão e Direitos da Personalidade: Uma análise argumentativa no âmbito do STJ.

Disponível em: http://www.pucrio.br/pibic/relatorio_resumo2013/relatorios_pdf/ccs/DIR/DIRLuisa\%20Soares\%20Ferreira\%20Lobo.pdf. Acesso em: 20 de set. de 2014.

MENDES, Gilmar Ferreira. Colisão de direitos fundamentais: liberdade de expressão e de comunicação e direito à honra e à imagem. Disponível em http://www.gilmarmendes.org.br. Acesso em 20 de set. de 2014.

MINOIS, George. História do riso e do escárnio. Tradução: Maria Helena O. Ortiz Assumpção. São Paulo: Editora UNESP,2003, p. 633.

NETTO, Domingos Franciulli. A proteção ao Direito à Imagem e a $\begin{array}{llll}\text { Constituição } & \text { Federal. } & \text { Disponível }\end{array}$ http://www.stj.jus.br/publicacaoseriada/índex.php/informativo/article/downl oad/303/287. Acesso em 28 de out de 2014.

NOBRE JUNIOR, Edilson Pereira. Liberdade de Expressão versus Direitos da Personalidade. $\quad$ Disponível em http://www2.cjf.jus.br/ojs2/index.php/revcej/article/viewFile/1163/1257. Acesso em: 20 de set. de 2014.

OLIVEIRA, Mônica Lopes Smiderle de. A ironia como produção do humor e crítica social: uma análise pragmática das tiras de Mafalda. Disponível em: http://periodicos.ufes.br/contextoslinguisticos/article/view/5270/3947. Acesso em: 15 de set. de 2014. 
OLIVEIRA, Zamara Graziela Pinheiro. Imprensa alternativa e ditadura militar - o humor subversivo de Hensfil nas páginas do Pasquim. Disponível em: http://www.uel.br/eventos/eneimagem/anais2011/trabalhos/pdf/Zamara\%20 Graziela\%20Pinheiro\%20de\%20Oliveira.pdf, p. 1. Acesso em 20 de set. de 2014.

PESSOA, Flavio Mota de Lacerda. A crítica social e política na charge esportiva (sic) de Henfil. Disponível em: http://www.snh2011.anpuh.org/resources/anais/14/1312814928_ARQUIV O_ACriticasocialepoliticanachargeesportivadeHenfilrevisadoem08deagosto de2011.pdf. Acesso em 10 de set. de 2014.

PIRES, Paulo Sérgio. Difíceis delimitações no "jornalismo humorístico". In: Observatório $\mathrm{da}$ Imprensa. Disponível em: http://200.169.104.103/news/view/dificeis_delimitacoes_no_jornalismo_hu moristico. Acesso em 10 de ago. de 2014.

RAY, Amber. Obama's toughest 2012 interview: Jon Stewart -- VIDEO. Disponível em: http://popwatch.ew.com/2014/04/18/obama-jon-stewartinterview/. Acesso em 26 de set. de 2014.

REALE, Miguel. Limites à liberdade de expressão. Espaço Jurídico, jul./dez. $2010 . \quad$ Disponível em: editora.unoesc.edu.br/index.php/espacojuridico/article/download/.../1022. Acesso em: 20 de set. de 2014.

Reclamação 18776 ajuizada perante o STF pela Clínica de Direitos Humanos da UERJ contra a decisão de Protocolo no 158.287/2014. Disponível em: http://uerjdireitos.com.br/clinica-uerj-direitos-atua-emcaso-de-censura-ao-canal-porta-dos-fundos/. Acesso em 29 de out. 2014. 
REDONDO, Cristina López. La libertad de expresión en situaciones de conflicto. Valencia: tirant lo blanch alternativa. 2013

REIS, Daniel Aragão e ROLLEMBERG, Denise. Para que não se esqueça, para que nunca mais aconteça. Disponível em:

http://www.observatoriodaimprensa.com.br/news/view/liberdade_de_expre ssao_a_definicao_constitucional. Acesso em: 20 de set. de 2014.

SANCHOTENE, Carlos Renan Samuel. Mídia, humor e política: a charge da televisão. Disponível em: http://books.google.com.br/books?id=RDrcjEso6N4C\&pg=PA56\&lpg=PA $56 \& \mathrm{dq}=$ cabaré + do + barata + artigos + humor $\&$ source $=$ bl\&ots $=$ Dqxn0bLvP\&sig=_3PT4eoTw_CzdF8dBvEBuuDulZ0\&hl=pt-

$\mathrm{BR} \& \mathrm{sa}=\mathrm{X} \& \mathrm{ei}=8 \mathrm{DRYVOqsMoObgwSSvoHYDw} \&$ redir_esc $=\mathrm{y} \# \mathrm{v}=$ onepage $\& q=$ cabaré\%20do\%20barata\%20artigos\%20humor\&f=false. Acesso em: 20 de out. de 2014.

SOARES, Ana Carolina Trindade Soares. Dos limites às restrições aos Direitos Fundamentais. Disponível em: http://amplodireito.com.br/noticia/60/artigos/2012/06/08/dos-limites-asrestricoes-aos-direitos-fundamentais. Acesso em 27 de out. de 2014.

STF, ADI 4451 MC, Rel. Min. Ayres Britto, julgado em 26/08/2010, DJ 01/09/2010.

STJ REsp. 984.803. Rel. Min. Nancy Andrighi, julgado em 26 de maio de 2009. 
TJSP. Processo número 583.00.2011.201838-5. $18^{\mathrm{a}}$ vara Cível de São Paulo. Sentença proferida pelo juiz Luiz Beethoven Giffoni Ferreira. Disponível em: http://www.dizerodireito.com.br/2012/01/como-muitos-devoces-ja-devem-saber-o.html. Acesso em 01 de nov. de 2014.

TJRJ. 3a Câmara Cível do Estado do Rio de Janeiro. Apelação Cível 14942/09. Relator: Desembargado Luiz Fernando Ribeiro de Carvalho. Rio de Janeiro, 10 de fev. De 2012

TJSP. $9^{a}$ Câmara de Direito Privado Tribunal de Justiça de São Paulo Rel. Des. Sérgio Gomes, agravo de instrumento No. 243.037-4/6, 8/06/2002.

TJSP. $6^{\text {a }}$ Câmara de Direito Privado do Tribunal de Justiça de São Paulo, , apelação 0017967-08.2008.8.26.0510, em 31/07/2014.

TJSP. 8a Câmara de Direito Privado do Tribunal de Justiça de São Paulo. Apelação 9199619-40.2009.8.26.0000. Relator: Pedro de Alcantara da Silva Leme Filho. São Paulo, 1 de outubro de 2014.

TJSP. 3a Camara de Direito Privado do Tribunal de Justiç a de São Paulo. Apelação número 0000465-52.2012.8.26.0272, da Comarca de Itapira. Relator: Desembargadora Viviani Nicolau. São Paulo, 3 de julho de 2014. 